تأثير زوال بذر و يتانسيل آب بر شاخصهاى جوانهزنى و بيوشيميايى بذر زياه شنبليله (Trigonella foenum-graecum)

\author{
حسن تيمورى'، حميد رضا بلوجى “`"، على مرادى"، الياس سلطانى "ه
}

جكيده مبسوط

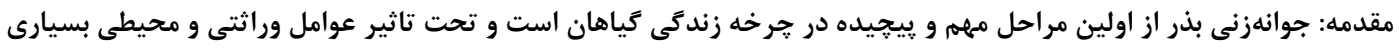

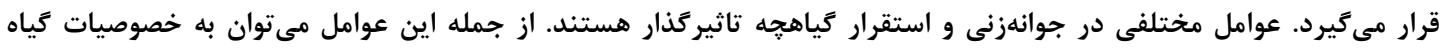

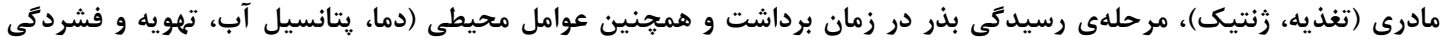

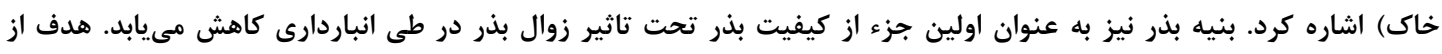

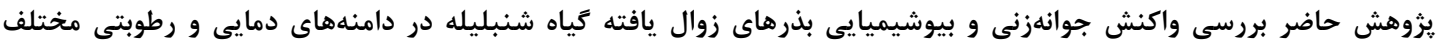

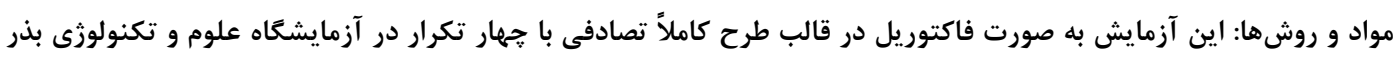

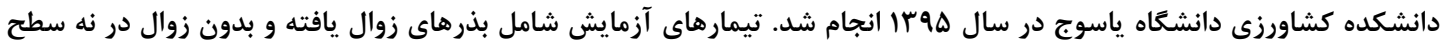

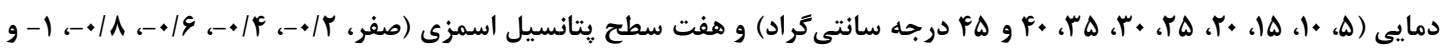

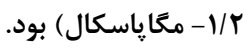

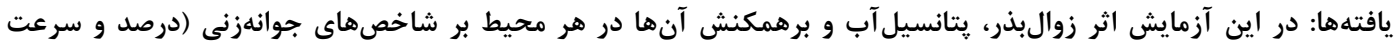

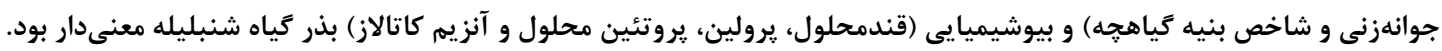

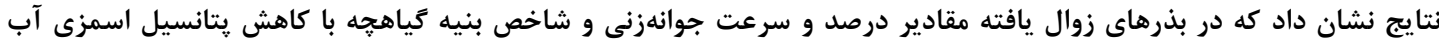

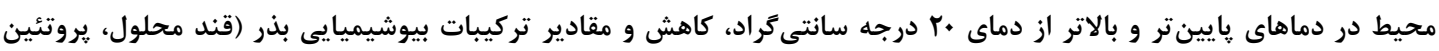

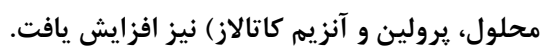

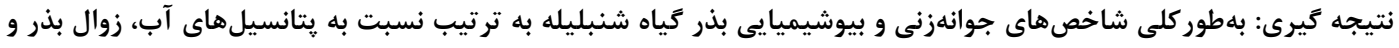

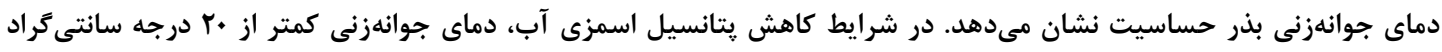

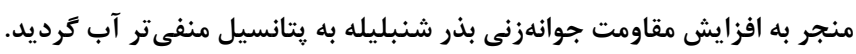
وازههاى كليدى: بنيه بذر، يرولين، تنش خشكى، درصد جوانهزنى، قندمحلول، كاتالاز

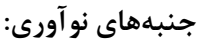

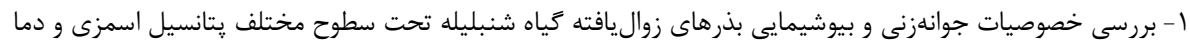

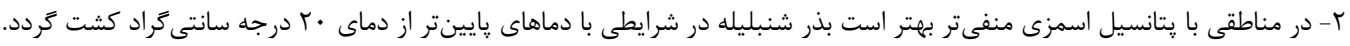

دانشجوى كارشناسى ارشد علوم و تكنولوزى بذر، دانشكده كشاورزى، دانشگاه ياسوج

http://dorl.net/dor/20.1001.1.23831251.1397.5.2.10.5

http://dx.doi.org/10.29252/yujs.5.2.105

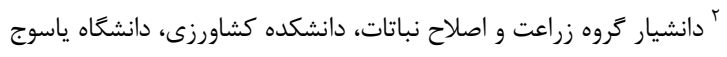

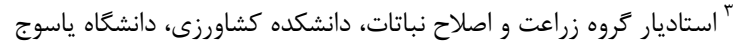

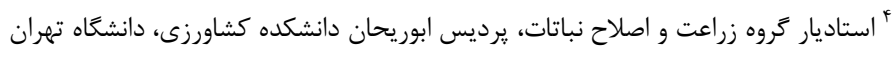

CrossMark

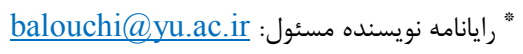

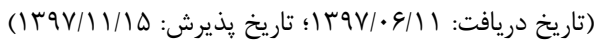


كاهش و يا مهار شود (هخارتى ^، 19V1). در مطالعهاى

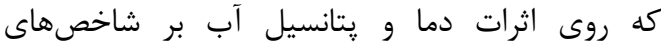

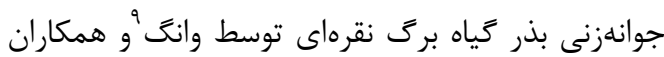

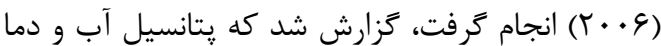

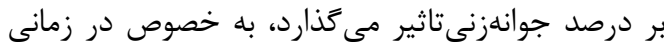

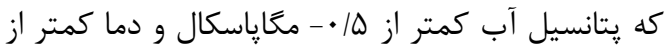

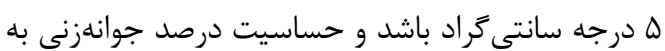
تغييرات يتانسيل آب بيشتر از تغييرات دما مى باشد.

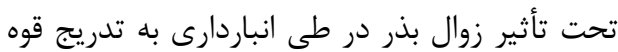

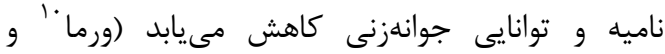

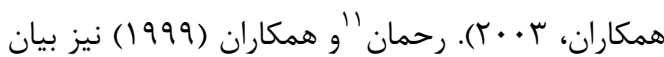
داشتند در شرايط زوال، بنيه بذر به عنوان اولين جزء آندان آندان

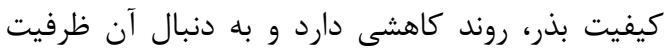

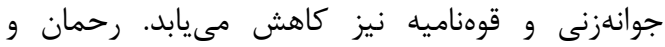

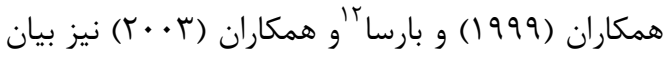
داشتند كه زوال به طور معنىدارى جوانهزدن و سبز شدن بذر را كاهش مىدهد. يس زوال بذر در طول دوره

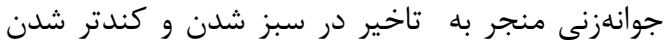

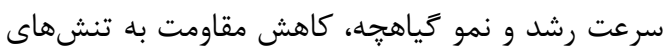
محيطى و كاهش جوانهزنى مى اخر جه با از دست رفتن قابليت حيات در برخى از نواحى

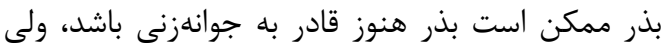
كياهجهى آن به واسطهى عدم كاركرد نواحى زواليافته،

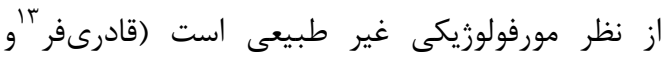

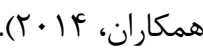

با بيشرفت زوال بذر، نفوذ رذيرى انتخابى غشاهاى سلولى از بين مىروند و در نتيجه آن، مواد سيتويلاسمى بلئي

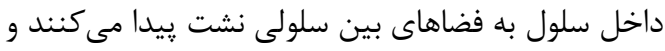
به دليل هيدروليز فسفوليييدهاى غشا و اكسيداسيون خود به خود آنها غشا سلولى آسيب مىبيند (قادرىفر فئر

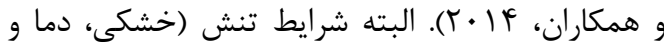

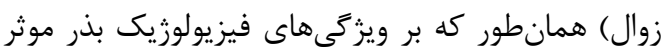

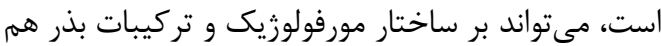

\footnotetext{
${ }^{8}$ Hegarty

${ }^{9}$ Wang

${ }^{10}$ Verma

${ }^{11}$ Rehman

${ }^{12}$ Barsa

${ }^{13}$ Qaderifar
}

مقلمهـ

بذر به عنوان يكى از اصلىترين بخشهاى گياهان مىباشد، كه تا به امروز ضامن بقاى كياهان بوده است.

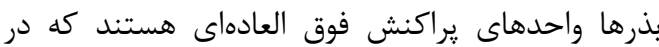

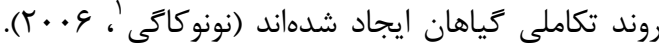
جوانهزنى بذر از مههترين و يِيجيدهترين مراحل خرخه

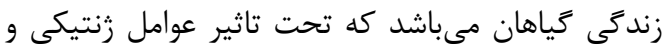
محيطى قرار مى گيرد. تاخير و استقرار نامناسب كياهجه از معضلات مهم در نواحى است كه كياهان با تنشهاى محيطى مانند تنش خشكى و دماى پإيين مواجه هستند

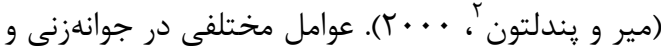
استقرار گياهجه تاثير گذار هستند از جمله اين عوامل مىتوان به خصوصيات زياه مادرى (تغذيه، زنتيك)، مرحلهى رسيدگى بذر در به زمان برداشت، صدمات مكانيكى، קِاتوزنها (آفات و بيمارىها) و همجنينين عوامل

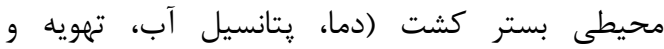
فشردىى خاك) اشاره كرد كه جوانهزنى و طويل شدن و سبز شدن گياهجه و در نتيجه نرخ مرك و مير كياهجه

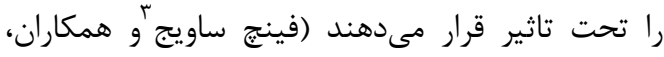

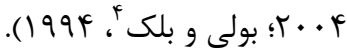
مهمترين عوامل محيطى تنظيم كننده جوانهزنى

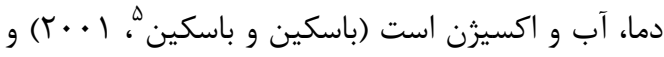
در شرايطى كه اكسيرن محدود كننده جوانهزنى نيست، دما و رطوبت عمدهترين نقش را در كنترل جوانهزنى

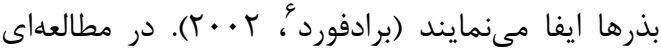

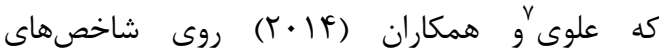

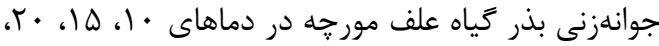

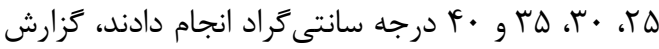

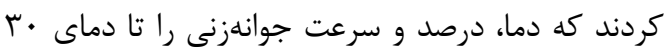

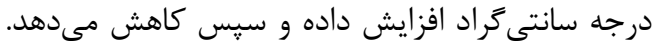

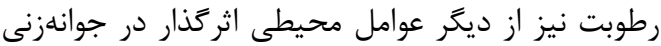

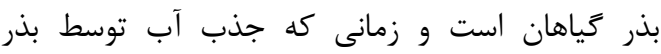
كاهش پيدا كند جوانهزنى ممكن است دجار تاخير،

\footnotetext{
${ }^{1}$ Nonogaki

${ }^{2}$ Meyer and Pendelton

${ }^{3}$ Finch-Savage

${ }^{4}$ Bewley and Black

${ }^{5}$ Baskin and Baskin

${ }^{6}$ Bradford

${ }^{7}$ Alavi
} 
بذر شنبليله مورد آزمايش از توده كاكان ياسوج و

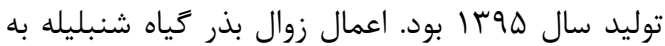
روش پِيرى تسريع شده به مدت له ساعت بر اساس

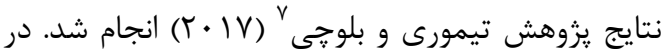

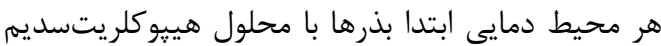
(يك درصد) به مدت يك دقيقه ضدعفونى شده و سيس

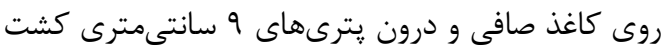
شدند. معيار براى جوانهزنى بذرها خروج ريشهاي

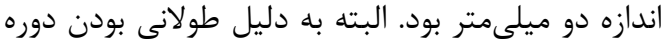
كشت و در نتيجه آن كاهش مقدار آب درون يترىها، مرطوب كردن مجدد بستر كشت در روز هفتم كشت به

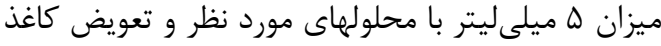

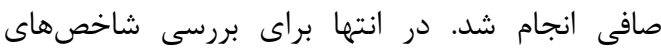

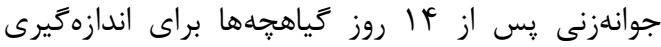
طول و وزن از يترىها خارج شدند. شاخصهاى جوانهزنى مورد مطالعه در اين بخش شامل درصد

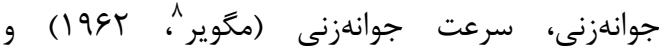

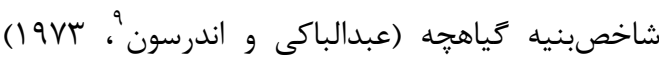

(n/N)×100 = درصد جوانهزنى

كه n: تعداد بذرهاى جوانهزده و N: تعداد كل بذرها بود. (1i

كه ni تعداد بذرهاى جوانهزده در هر شمارش و ti

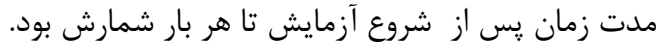
(GP×SS)/100

كه SS: طول كَياهحه (ميلىمتر) و GP: درصد جوانهزنى

اندازهيرى شاخصهاى بيوشيميايى از بذر و در

مرحله آبنوشى صورت كرفت. البته زمان انجام اين إندائ

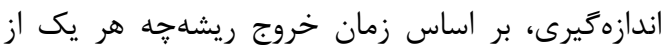
تيمارها در محيطهاى دمايى مختلف در بخش آنش اول

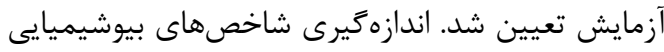

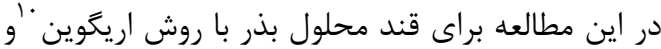

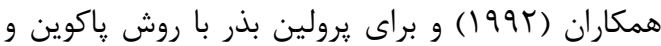

\footnotetext{
${ }^{7}$ Teimori and Balouchi

${ }^{8}$ Maguire

${ }^{9}$ Abdul-Baki and Anderson

${ }^{10}$ Irigoyen
}

مؤثر باشد. تركيبات آنتىاكسيدانى همجون آنزيمهاى

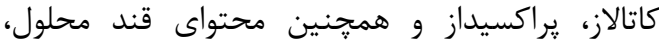
يروتئين و يرولين از جمله تركيباتى هست كه در اثراثين وجود شرايط تنشى همجِون زوال، خشكى و ودما دجار تغييرات معنى دار خواهند شد (شعبان'،

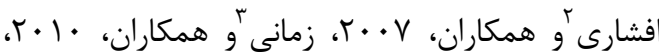

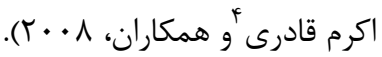

كياه شنبليله با نام علمى - Trigonella foenum Fabaceae (و و از تيره نيامداران graecum L. مىباشد. بذرها و بركهاى كياه شنبليله در كشورهاى مختلف جهان جهت اهداف مختلف از جمله مصارف دارويى (ضد ديابت، كاهش قند و سطح كلسترول خون، ضد سرطان، ضد ميكروب و غيره)، خوراكى، تهيه آفت كشها، صنايع عطرسازى و غيره مصرف مئشون

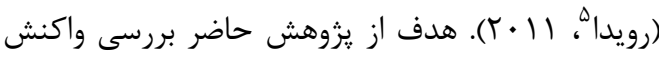
جوانهزنى و بيوشيميايى بذرهاى زوال يافته گياه شنبليله در دامنههاى دمايى و رطوبتى مختلف بود.

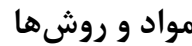
اين يزوهش در آزمايشحاه علوم و تكنولوزى بذر كروه زراعت و اصلاح نباتات دانشكده كشاورزى دانشعاه ياسوج در سال هوسا و به صورت آزمايش فاكتوريل در

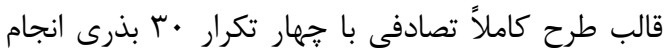
شد. در اين يزوهش دما به عنوان محيط و زوال بذر و

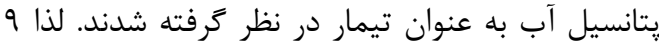

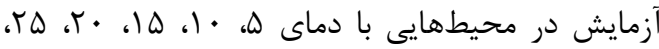

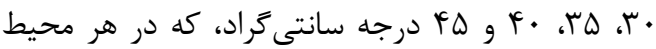

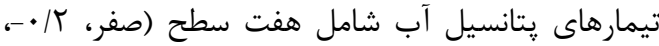

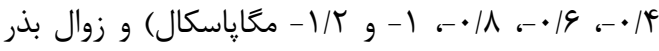
در دو سطح (بدون زوال و بذرهاى زواليافته) به صورت

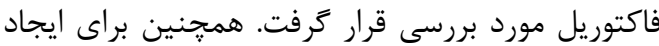
سطوح يتانسيل اسمزى آب از يلىاتيلن كلايكول ... .9.

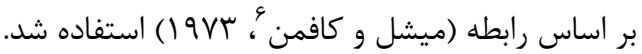

\footnotetext{
${ }^{1}$ Shaban

${ }^{2}$ Tavakol Afshari

${ }^{3}$ Zamani

${ }^{4}$ Akram Ghaderi

${ }^{5}$ Ruveyda

${ }^{6}$ Michel and Kaufmann
} 
اسيكتروفوتومتر قرائت شد و غلظت يروتئين نمونهها بر

حسب ميلى

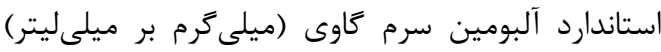

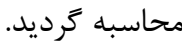
در اين آزمايش براى اندازهيرى ميزان فعاليت آنزيم

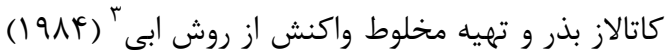

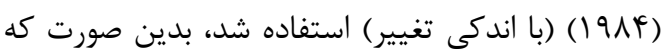
از عصاره يروتئينى براى اندازمخيرى ميزان فعاليت آنزيم

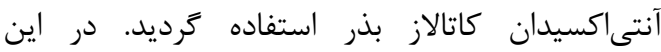

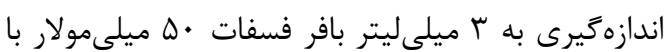

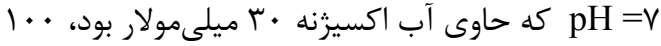

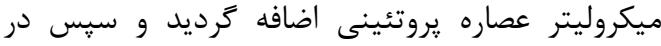

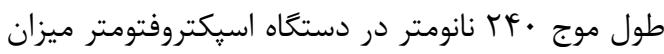
كاهش جذب در مدت زمان • • ثانيه قرائت شد. در اين

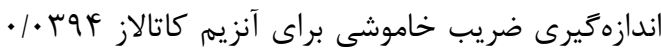

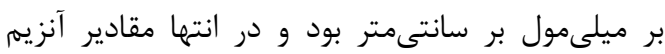

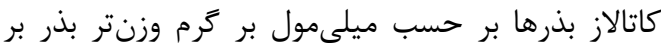
دقيقه محاسبه شد.

با توجه به اين كه هر سطح دمايى به عنوان يك داسن محيط و آزمايش مستقل انجام گرديد و با توجه به نتايج آزمون بارتلت و عدم تجانس واريانسها تجزيه مركب

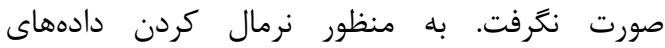
شاخصهاى جوانهزنى بذر تبديل ريشهاى x+1 دادهها انجام شد و سيس تجزيه واريانس و محاسبات آمارى تدى دادههاى حاصل از بخش اول و دوم آزمايش بإيا استفاده از نرم افزار آمارى 9.1 SAS و مقايسه ميانكينها با با آزمون LSD در سطح احتمال ينج درصد انجام شد و براى

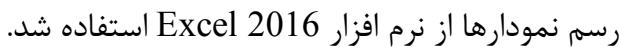

نتايج و بحث

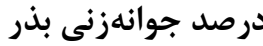

نتايج تجزيه واريانس دادهها براى درصد جوانهزنى

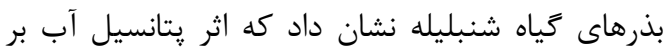
اين شاخص در تمامى دماهاى مورد آزمايش معنى دار بود، اثر زوال بذر و همجنين برهمكنش ريتانسيل آب و داري

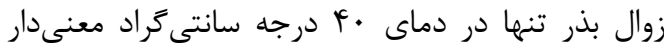

\footnotetext{
${ }^{3}$ Aebi
}

لجاسور' (9V9 (199) انجام شد، براى اندازمكيرى قندهاى محلول به ميزان // • ميلىليتر از عصاره الكلى هر نمونه

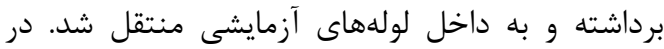

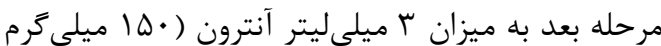

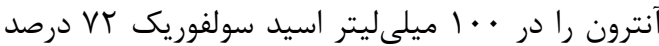
مخلوط كرده و سيس به مدت زمان • ل دقيقه در حمام آب جوش دستخاه بن مارى قرار كرفت. در انتها ميزان جذب نمونهها در طول موج اسيكتروفتومتر قرائت گرديد و با توجه بله نمودار استاندارد كلوگز (ميلى گرم بر ليتر) مقادير قندهاى محلول نمونهها بر اساس ميلى

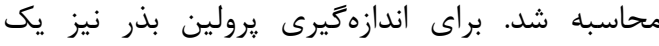

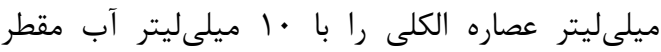

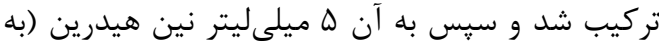

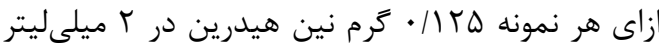
اسيد فسفوريك و مولار و ب ميلى ليتر استيك اسيد كلاسيال (99/9 درصد) اضافه كرديد و به مدت زمان زمان 19

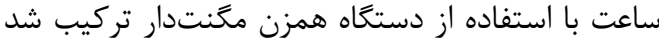
و در مرحله بعد ه ميلىليتر استيك اسيد كلاسيال به

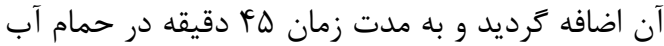

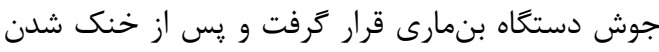

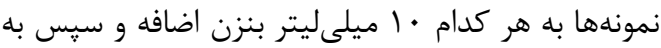
شدت تكان داده شد تا برولين درون نمونهها وارد فاز

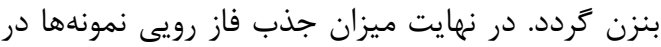
طول موج هاه هانومتر با دستكاه اسيكتروفتومتر قرائت شد و با توجه به مقادير استاندارد ال-يرولين (ميكرومول بر ميلىليتر)، ميزان يرولين نمونهها بر اساس ميكرومول بر كرم وزنتر بذر محاسبه شد. براى اندازَيرى يروتئين بذر نيز از روش روش كار و و

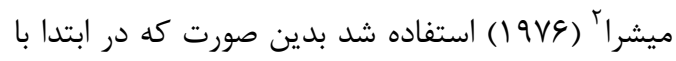
استفاده از بافر فسفات קتاسيم با pH=9/1 استخراج

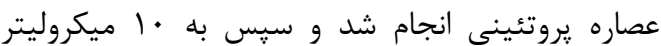
عصاره يروتئينى هر نمونه •99 ميكروليتر محلول

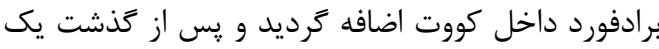

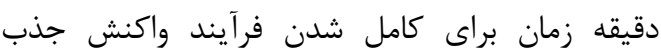
نمونهها در طول موج ه9 هان نانومتر در دستخاه

\footnotetext{
${ }^{1}$ Paquin and Lechasseur

${ }^{2}$ Kar and Mishra
} 
در مطالعهاى روى شاخصهاى جوانهزنى بذر گياه كتان روغنى تحت يتانسيلهاى آب، كزارش كردند كه با كاهش سطوح مختلف پֶتانسيل آب در شاخص درصد جوانهزنى بذرها روند كاهشى مشاهده شد، به كونهاي كه بيشترين مقدار اندازهكيرى شده در تيمارهاى شاهد و

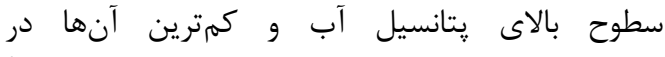

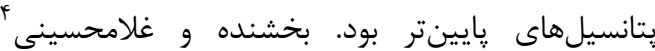

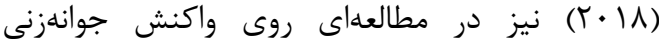
بذرهاى گياه سويا تحت شرايط زوال بذر و رتانسيلهاى مختلف آب، بيان داشتند كه درصد جوانهزنى با افزايش زوال بذر (صفر تا VY Vاعت) و همجنين كاهش

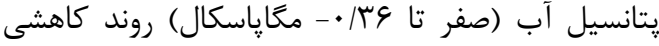

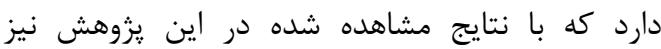
مشابهت داشت.

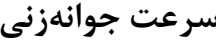

نتايج تجزيه واريانس دادهها براى سرعت جوانهزنى بذرهاى كياه شنبليله نشان داد كه اثر يتانسيل آب در

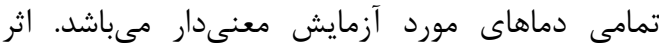
زوالبذر و برهمكنش يتانسيل آب و زوال بذر نيز در دراد

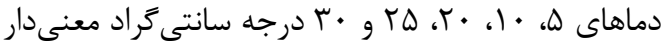
بود. در اين آزمايش كاهش يتانسيل آب در محيطهاى

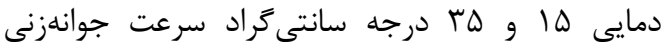
بذرهاى گياه شنبليله را نسبت به يتانسيل صفر كاهش داد و به صفر رساند و بيشترين ميزان سرعت جوانهزنى دانى داني

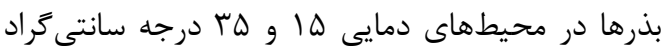
در يتانسيل آب صفر مغاياسكال مشاهده شد و در محيط

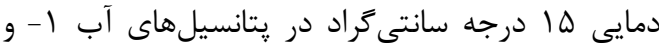

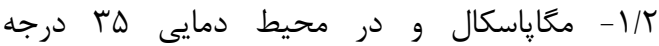

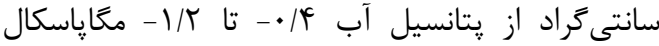
جوانهزنى مشاهده نشد (شكل كآ). نتايج اين آزمايش

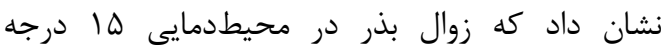

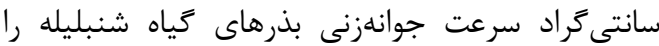
نسبت به سطح بدون زوال ه/ه الدرصد كاهش دادي همجنين بيشترين ميزان سرعت جوانهزنى بذرها در محيطدمايى ها دارجه سانتى كراد در سطح بدون زوال

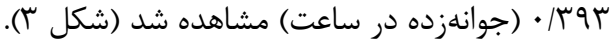

\footnotetext{
${ }^{4}$ Bakhshandeh and Gholamhossieni
}

بود (دادهها ارائه نشده است). نتايج مقايسه ميانكين اثر

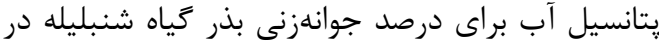

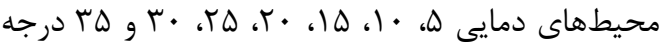
سانتى كراد نشان داد كه ميزان درصد جوانهزنى بذرها با دمان كاهش يتانسيل آب روند كاهشى دارد و بيشترين مقدار درصد جوانهزنى در محيطهاى دمايى ه تا ها لـ درجه سانتى كراد در سطح صفر يتانسيل آب مشاهده شد. دران همجنين نتايج درصد جوانهزنى بذرها در تمامى سطوح

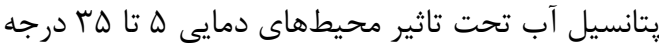
سانتى محدودمى دماى بهينه (•r درجه سانتى كراد) روند كاهشى نشان داد (جدول (1). نتايج اين آزمايش نشان

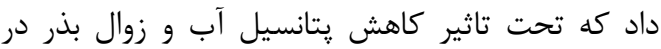

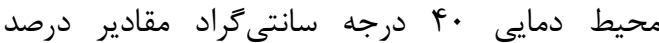
جوانهزنى بذرهاى كياه شنبليله نسبت به يتانسيل آبى درئ داني صفر كاهش مىيابد و به صفر مىرساند، بيشترين ميزان درصد جوانهزنى (ا الدرصد) در اين دما در بذرهاى بدون

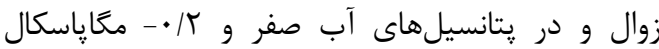
مشاهده شد كه در مقدار با يكديكر تفاوت معنىدارى نداشتند. همجنين در اين محيط دمايى در بذرهاى

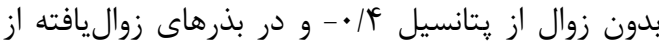

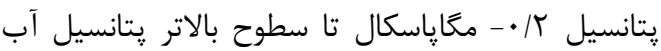
جوانهزنى مشاهده نشد (شكل ().

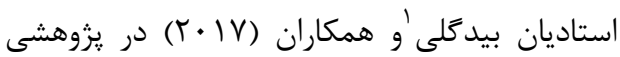
روى شاخصهاى جوانهزنى بذر كياه كلرنت رقم صفه تحت تأثير دما و يتانسيلهاى آب بيان داشتند كه به به

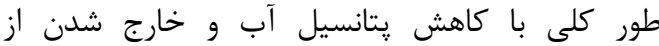
محدودهى دماى بهينه، درصد جوانهزنى بذرها كاهش بافي يافت. يس با توجه به كاهش ميزان دسترسى به آب در دران سطوح پايينتر پتانسيل آبى ناشى از يلىاتيلنكلايكول

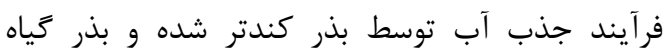
شنبليله مدت زمان بيشترى را براى رسيدن به يتانسيل

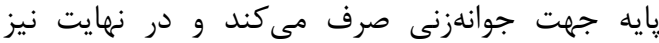

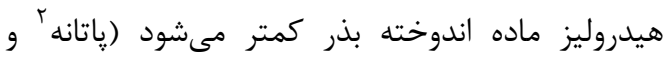

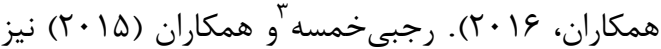

\footnotetext{
${ }^{1}$ Ostadian bidgoly

2 Patane

${ }^{3}$ Rajabi khamseh
} 
جدول ا. مقايسه ميانكين اثر يتانسيل آب، براى درصد جوانهزنى بذر كياه شنبليله در دماهاى مورد آزمايش

Table 1. Mean comparison of the effect of water potential on germination percentage of Fenugreek at test temperatures

\begin{tabular}{|c|c|c|c|c|c|c|c|}
\hline \multirow{2}{*}{$\begin{array}{c}\text { يتانسيل آب (MPa) } \\
\text { Water potential (MPa) }\end{array}$} & \multicolumn{7}{|c|}{ Tomperature $\left({ }^{\circ} \mathrm{C}\right)$} \\
\hline & 5 & 10 & 15 & 20 & 25 & 30 & 35 \\
\hline 0 & $99.5^{\mathrm{a}}$ & $98.5^{\mathrm{a}}$ & $99^{\mathrm{a}}$ & $100^{\mathrm{a}}$ & $100^{\mathrm{a}}$ & $96.5^{\mathrm{a}}$ & $61.5^{\mathrm{a}}$ \\
\hline-0.2 & $98.5^{\mathrm{a}}$ & $99^{\mathrm{a}}$ & $98^{\mathrm{a}}$ & $99^{\mathrm{a}}$ & $96.5^{\mathrm{a}}$ & $75.5^{\mathrm{b}}$ & $4.5^{\mathrm{b}}$ \\
\hline-0.4 & $98.5^{\mathrm{a}}$ & $96.5^{\mathrm{a}}$ & $99^{\mathrm{a}}$ & $95.5^{\mathrm{a}}$ & $10^{\mathrm{b}}$ & $0^{\mathrm{c}}$ & $0^{c}$ \\
\hline-0.6 & $97.5^{\mathrm{a}}$ & $59^{\mathrm{b}}$ & $58^{\mathrm{b}}$ & $76^{\mathrm{b}}$ & $0.5^{\mathrm{c}}$ & $0^{\mathrm{c}}$ & $0^{\mathrm{c}}$ \\
\hline-0.8 & $58.5^{\mathrm{b}}$ & $35.5^{\mathrm{c}}$ & $8^{c}$ & $0^{\mathrm{c}}$ & $0^{\mathrm{c}}$ & $0^{\mathrm{c}}$ & $0^{\mathrm{c}}$ \\
\hline-1 & $0^{\mathrm{c}}$ & $0^{\mathrm{d}}$ & $0^{c}$ & $0^{\mathrm{c}}$ & $0^{\mathrm{c}}$ & $0^{\mathrm{c}}$ & $0^{\mathrm{c}}$ \\
\hline-1.2 & $0^{\mathrm{c}}$ & $0^{\mathrm{d}}$ & $0^{\mathrm{c}}$ & $0^{\mathrm{c}}$ & $0^{\mathrm{c}}$ & $0^{\mathrm{c}}$ & $0^{\mathrm{c}}$ \\
\hline
\end{tabular}

In each column, the same letters indicate no significant difference based on the LSD test at the $5 \%$ level.

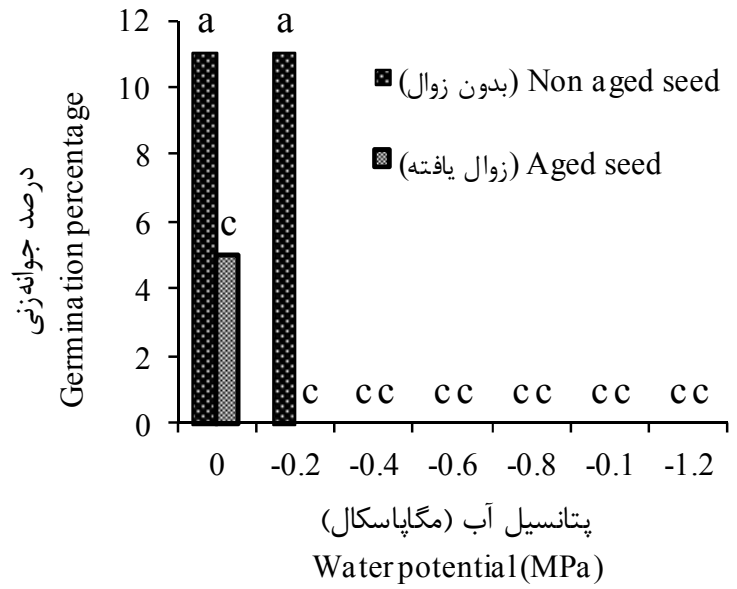

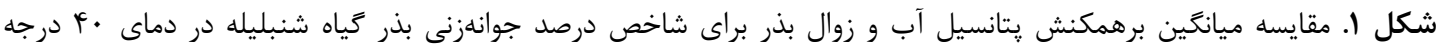

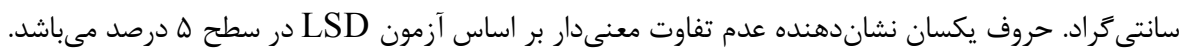

Fig. 1. Mean comparison of interaction effect of water potential and seed aging on germination percentage of Fenugreek at $40{ }^{\circ} \mathrm{C}$ temperature. The same letters indicate no significant difference based on the LSD test at the $5 \%$ level.

محيطهاى دمايى بر ميزان سرعت جوانهزنى تحت

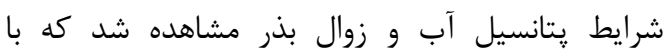

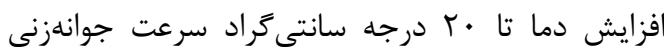

افزايش مىيابد و سيس با افزايش دما از • · درجه

سانتى كراد ميزان سرعت جوانهزنى روندى كاهشى دارد.

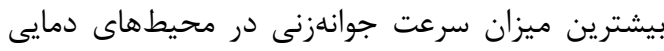

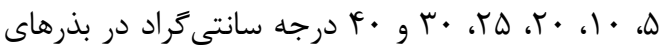

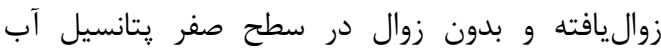

نتايج مقايسه ميانكين برهمكنش ريتانسيل آب و

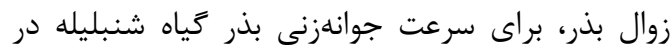

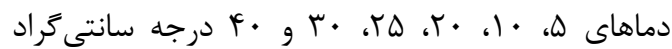

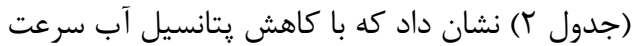

جوانهزنى بذر خياه شنبليله در هر دو دسته بذرهاى دائ

زواليافته و بدون زوال روند كاهشى داشت و بهاطور كلى دئى

اين روند كاهشى سرعت جوانهزنى در بذرهاى زواليافته

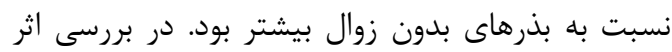


داشتند كه سرعت جوانهزنى با افزايش زوال بذر (صفر تا

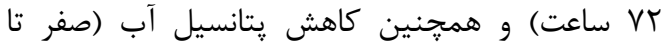
عr/•- مخاياسكال) روند كاهشى دارد و و تاثيريذيرى شاخص سرعت جوانهزنى بذرها از يتانسيلهاى مختلف رئف آب نسبت به شرايط زوال بذر بيشتر بود كه با نتايج مشاهده شده در اين يزوهش نيز مطابقت داشت.

\section{شاخص بنيه كياهجه}

اثر يتانسيل آب و اثر زوالبذر بر شاخص بنيه

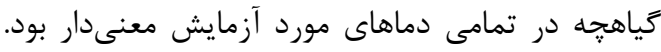
برهمكنش يتانسيل آب و زوال بذر نيز در تمامى دماهاى دماى داني

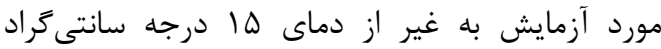

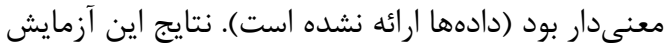

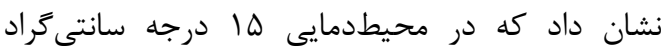

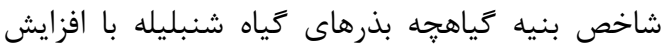

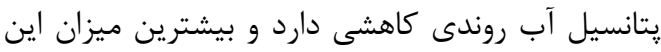

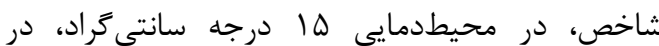
يتانسيل آب صفر مغاياسكال مشاهده مىشود (شكل ثأ).

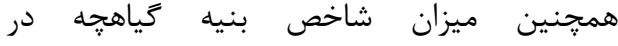

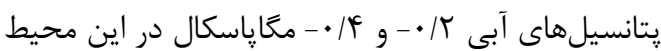
دمايى تفاوت معنى دارى نداشتند (شكل \&) أن نتايج اين يزوهش نشان داد كه در محيطدمايى لها درجئ داني

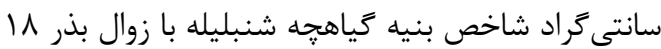
درصد نسبت به بدون زوال كاهش مىيابد و بيشترين

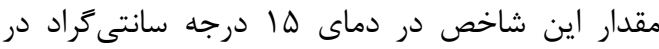
بذرهاى بدون زوال مىباشد كه نشاندهندهى تاثيرات كاهشى زوال بذر بر شاخصهاى جوانهزنى و بنيه بذر بذر باندان

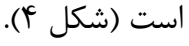

در اين مطالعه با كاهش يتانسيل آب، شاخص بنيه كياهجه شنبليله در هر دو دسته بذرهاى زواليافته و

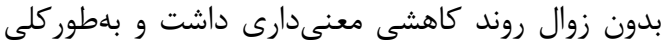

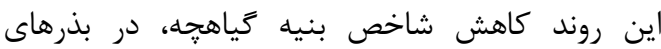
زواليافته نسبت به بذرهاى بدون زوال بيشتر بود. اين

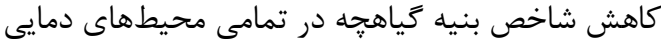

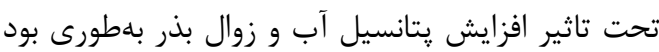
كه بيشترين ميزان اين شاخص در يتانسيل صفر و ورئ

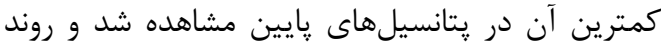

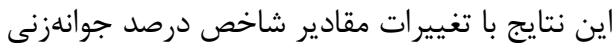

مشاهده شد. در بررسى برهمكنش يتانسيل آب و زوال بذر در دماهاى مختلف بر شاخص درصد و سرعت برد

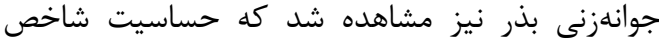

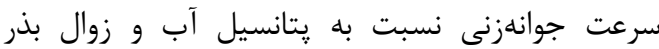

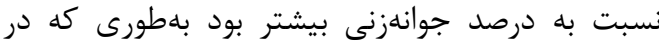

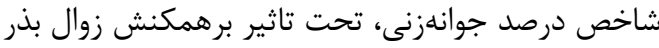

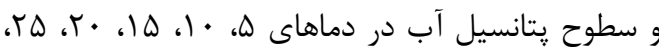

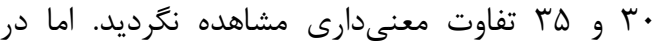
شاخص سرعت جوانهزنى اين تفاوت در تمامى دماها به

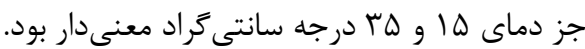

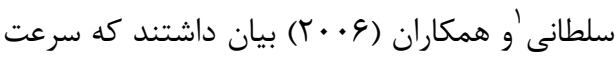
جوانهزنى نسبت به درصد جوانهزنى شاخص حساسترى به دما مىباشد. واكنش متفاوت مرحله جوانهزنى به دانه دماهاى مختلف به اين دليل است كه با افزايش دما تا تا دماى مطلوب، فعاليت آنزيمها و به تبع آن كارئ آنايى واكنشهاى آنزيمى افزايش مىيابد كه اين امر بهبود

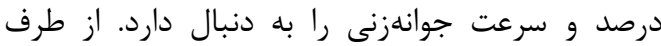
ديكر، دماهاى خيلى كم و زياد نيز موجب غير فعال

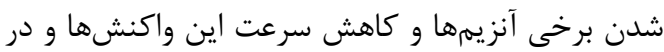
نتيجه كاهش درصد جوانهزنى مىشود. در دماهاى

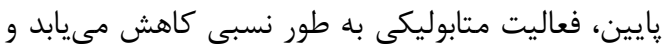
واكنشهاى گياهى نمىتوانند در كياه انجام گيرند، ازئ طرف ديكر دماهاى زياد براى مدت زمان طولانى باعث

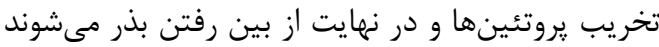

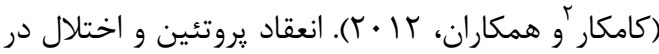
كار غشاها از جمله عواملى است كه باعث كاهش سرعت جوانهزنى بذرها در دماهاى بيشتر از دماى مطلوب

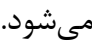
در يزوهشى بر شاخصهاى جوانهزنى بذر كياه

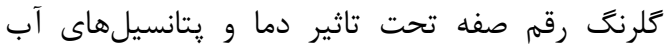

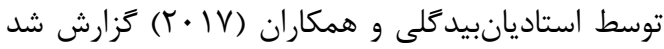

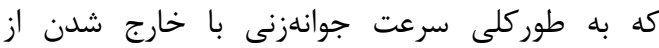

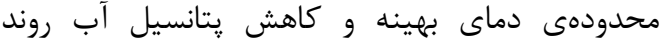

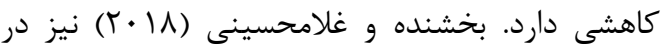
مطالعهاى روى واكنش جوانهزنى بذرهاى كياه سويا تحت شرايط زوال بذر و يتانسيلهاى مختلف آب بيان

\footnotetext{
${ }^{1}$ Soltani

${ }^{2}$ Kamkar
} 


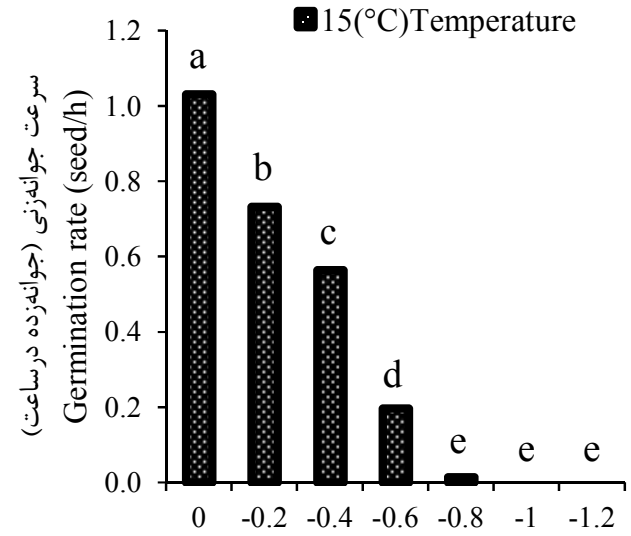

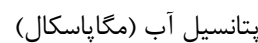

Water potential (MPa)

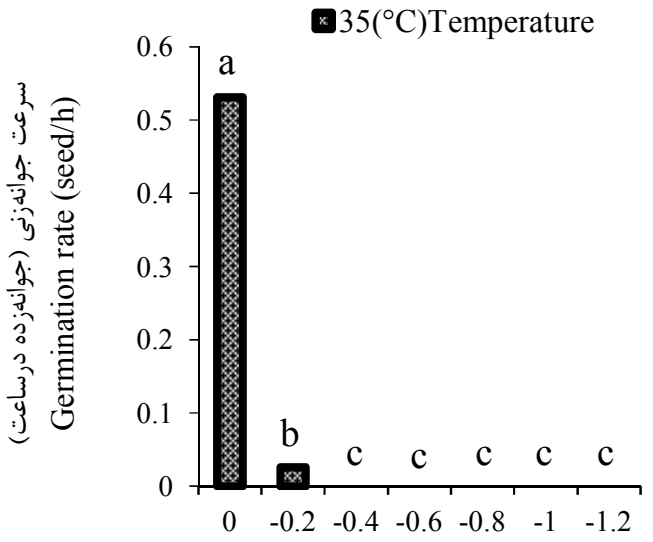

يتانسيل آب (مغاياسكال) Water potential (MPa)

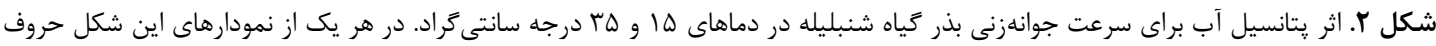
يكسان نشاندهنده عدم تفاوت معنى ار برار بر اساس آزمون

Fig. 2. The Effect of Water potential on germination rate of Fenugreek at 15 and $35^{\circ} \mathrm{C}$ temperatures. In each section of this figure, the same letters indicate no significant difference based on the LSD test at the $5 \%$ level.

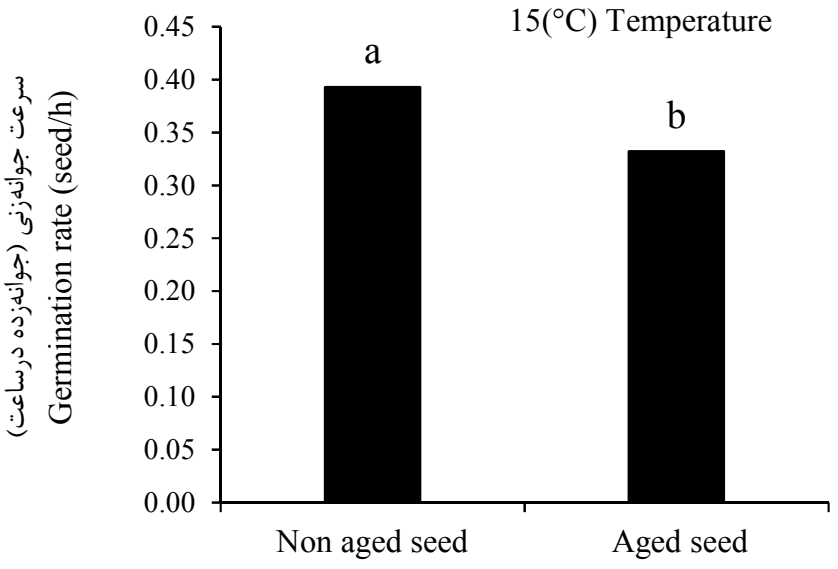

زوال بذر

Aged seed

شكل س. اثر زوال بذر براى سرعت جوانهزنى بذر كَياه شنبليله در دماى صا درجه سانتى كراد. حروف يكسان نشاندهنده عدم تفاوت معنى دار بر اساس آزمون LSD در سطح له درصد مى آنداشد.

Fig. 3. The Effect of seed aging on germination rate of Fenugreek at $15{ }^{\circ} \mathrm{C}$ temperature. The same letters indicate no significant difference based on the LSD test at the $5 \%$ level.

به دليل تخريب ساختارهاى غشا سلول (هيدروليز

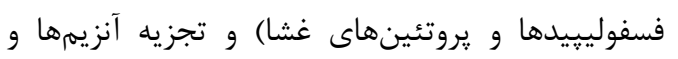

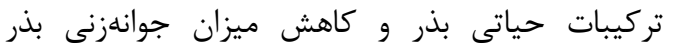

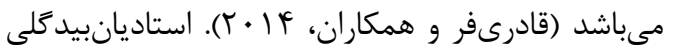

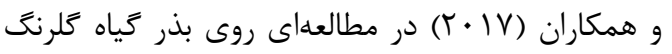

رقم صفه بيان داشتند كه بين طول زياهجه و زمان

$$
\begin{aligned}
& \text { بذرها مطابقت داشت. كاهش بنيه گياهجه تحت تاثير }
\end{aligned}
$$

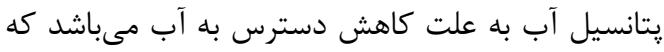

$$
\begin{aligned}
& \text { موجب مىشود تا فعاليت آنزيمها در انتقال اندوختههاى }
\end{aligned}
$$

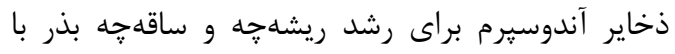

$$
\begin{aligned}
& \text { اختلال روبرو شود و همجنين ميزان جوانهزنى نيز } \\
& \text { كاهش يابد. كاهش بنيه گَياهجه تحت تاثير زوال بذر نيز }
\end{aligned}
$$




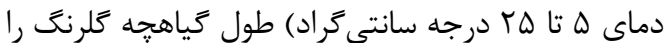

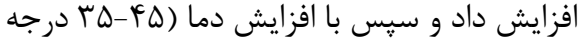

$$
\text { شروع جوانهزنى بذر گياه گلرنغ يك همبستگى مثبت }
$$

جدول r. مقايسه ميانگَين برهمكنش يتانسيل آب و زوال بذر، براى سرعت جوانهزنى (جوانهزده در ساعت) بذر گياه شنبليله در دماهاى مورد

Table 2. Mean comparison of interaction effect of water potential and seed aging on germination rate

\begin{tabular}{|c|c|c|c|c|c|c|c|}
\hline \multirow{2}{*}{$\begin{array}{c}\text { زوال بذر } \\
\text { Seed aging }\end{array}$} & \multirow{2}{*}{$\begin{array}{c}\text { يتانسيل آب (MPa) } \\
\text { Water potential (MPa) }\end{array}$} & \multicolumn{6}{|c|}{ Tomperature $\left({ }^{\circ} \mathrm{C}\right)$ دem } \\
\hline & & 5 & 10 & 20 & 25 & 30 & 40 \\
\hline \multirow{7}{*}{$\begin{array}{c}\text { بدون زوال } \\
\text { Non aged }\end{array}$} & 0 & $0.380^{\mathrm{a}}$ & $0.838^{\mathrm{a}}$ & $1.607^{\mathrm{a}}$ & $1.508^{\mathrm{a}}$ & $1.031^{\mathrm{a}}$ & $0.084^{\mathrm{a}}$ \\
\hline & -0.2 & $0.325^{\mathrm{b}}$ & $0.670^{\mathrm{bc}}$ & $1.107^{\mathrm{c}}$ & $0.886^{\mathrm{c}}$ & $0.289^{\mathrm{c}}$ & $0.084^{\mathrm{a}}$ \\
\hline & -0.4 & $0.205^{\mathrm{d}}$ & $0.452^{\mathrm{d}}$ & $0.712^{\mathrm{e}}$ & $0.048^{\mathrm{e}}$ & $0^{\mathrm{d}}$ & $0^{\mathrm{c}}$ \\
\hline & -0.6 & $0.140^{\mathrm{e}}$ & $0.255^{\mathrm{e}}$ & $0.171^{\mathrm{g}}$ & $0.004^{\mathrm{e}}$ & $0^{\mathrm{d}}$ & $0^{\mathrm{c}}$ \\
\hline & -0.8 & $0.049^{f}$ & $0.039^{\mathrm{fg}}$ & $0^{\mathrm{h}}$ & $0^{\mathrm{e}}$ & $0^{\mathrm{d}}$ & $0^{\mathrm{c}}$ \\
\hline & -1 & $0^{\mathrm{g}}$ & $0^{\mathrm{g}}$ & $0^{\mathrm{h}}$ & $0^{\mathrm{e}}$ & $0^{\mathrm{d}}$ & $0^{\mathrm{c}}$ \\
\hline & -1.2 & $0^{\mathrm{g}}$ & $0^{\mathrm{g}}$ & $0^{\mathrm{h}}$ & $0^{\mathrm{e}}$ & $0^{\mathrm{d}}$ & $0^{c}$ \\
\hline \multirow{7}{*}{$\begin{array}{l}\text { زواليافته } \\
\text { Aged }\end{array}$} & 0 & $0.314^{\mathrm{b}}$ & $0.731^{\mathrm{b}}$ & $1.456^{\mathrm{b}}$ & $1.257^{\mathrm{b}}$ & $0.848^{\mathrm{b}}$ & $0.023^{b}$ \\
\hline & -0.2 & $0.233^{\mathrm{c}}$ & $0.614^{\mathrm{c}}$ & $0.974^{\mathrm{d}}$ & $0.666^{\mathrm{d}}$ & $0.313^{\mathrm{c}}$ & $0^{\mathrm{c}}$ \\
\hline & -0.4 & $0.197^{\mathrm{d}}$ & $0.420^{\mathrm{d}}$ & $0.554^{\mathrm{f}}$ & $0.034^{\mathrm{e}}$ & $0^{\mathrm{d}}$ & $0^{\mathrm{c}}$ \\
\hline & -0.6 & $0.135^{\mathrm{e}}$ & $0.087^{\mathrm{f}}$ & $0.142^{\mathrm{g}}$ & $0^{\mathrm{e}}$ & $0^{\mathrm{d}}$ & $0^{\mathrm{c}}$ \\
\hline & -0.8 & $0.059^{f}$ & $0.046^{\mathrm{fg}}$ & $0^{\mathrm{h}}$ & $0^{\mathrm{e}}$ & $0^{\mathrm{d}}$ & $0^{\mathrm{c}}$ \\
\hline & -1 & $0^{\mathrm{g}}$ & $0^{\mathrm{g}}$ & $0^{\mathrm{h}}$ & $0^{\mathrm{e}}$ & $0^{\mathrm{d}}$ & $0^{\mathrm{c}}$ \\
\hline & -1.2 & $0^{\mathrm{g}}$ & $0^{\mathrm{g}}$ & $0^{\text {h }}$ & $0^{\mathrm{e}}$ & $0^{\mathrm{d}}$ & $0^{\mathrm{c}}$ \\
\hline
\end{tabular}
$(\mathrm{seed} / \mathrm{h})$ of Fenugreek at experimental temperatures

In each column, the same letters indicate no significant difference based on the LSD test at the 5\% level.

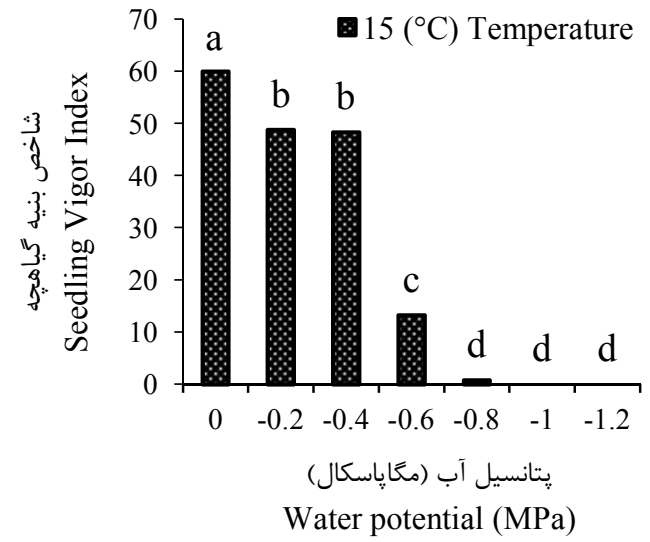

شكل F. اثر يتانسيل آب و زوال بذر بر شاخص بنيه گياهجه بذر گياه شنبليله در دماى ها درجه سانتى گراد. در هر يك از نمودارهاى اين شكل حروف

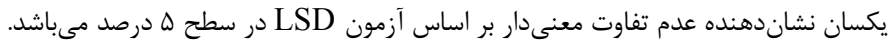

Fig. 4. The effect of water potential and seed aging on seedling vigor index of Fenugreek at $15{ }^{\circ} \mathrm{C}$ temperature. In each section of this figure, the same letters indicate no significant difference based on the LSD test at the $5 \%$ level. 


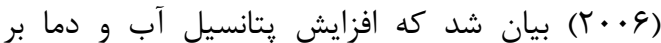

شاخصهاى جوانهنى و بنيه كَاهجهةتاثير كاهشى دارد.

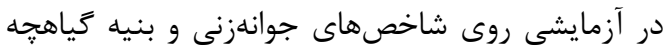

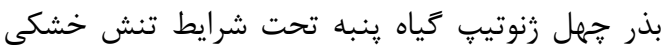

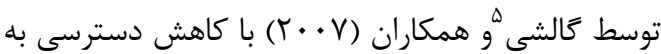

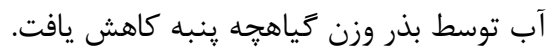

\section{محتواى قندهاى محلول بذر}

نتايج تجزيه واريانس دادههاى مربوط به قند محلول بلد بذر كياه شنبليله نشان داد كه اثر يتانسيل آب و و زوال بذر بر اين شاخص در تمامى دماهاى مورد آزمايش

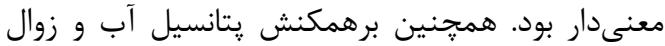

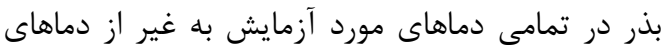

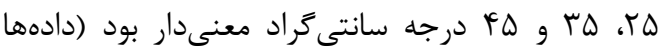

ارائه نشده است).

نتايج اين آزمايش نشان داد كه در محيطهاىدمايى

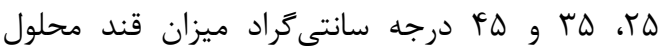
بذرهاى كياه شنبليله با كاهش يتانسيل آب (كاهش

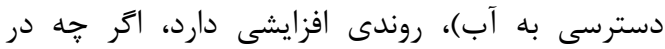

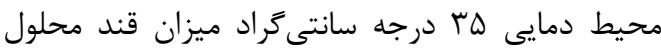

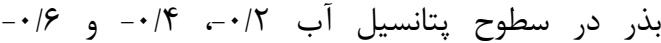

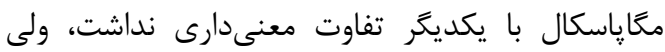

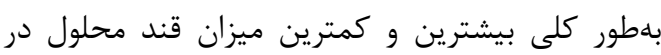

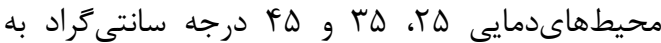
ترتيب در يتانسيل هاى 1/ إ و و صفر مغاياسكال مشاهده شد. بر اساس نتايج همجنين مشاهده كرديد افزايش دما

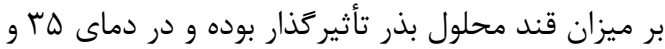
كائ درجه سانتى سانتى گراد در تمامى سطوح بتانسيل آب با افزايش دما، دان

ميزان قندهاى محلول بذر افزايش يافت (شكل ه). نتايج اين يزوهش نشان داد كه در محيطهاى دمايى

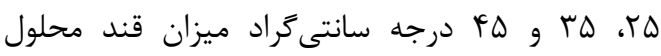
بذرهاى كياه شنبليله تحت تاثير زوال بذر به ترتيب

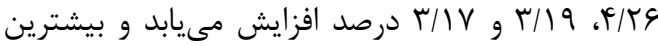

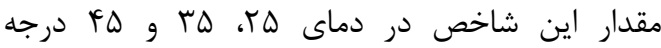

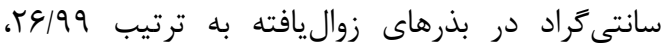

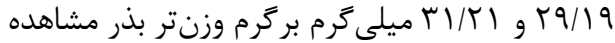

${ }^{5}$ Gallashi
سانتى كراد) مقادير اين شاخص كاهش يِيدا كرد. همجنين ايشان در بررسى اثر يتانسيلهاى مختلف

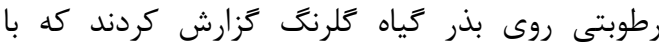
كاهش يتانسيل آب شاخصهاى طول و وزن كيان كياهجه

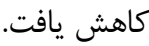

بلدى' همكاران (19 (T) نيز در بررسى اثر توام دما و رطوبت بر شاخصهاى جوانهزنى و بنيه بذر كياه كتان روغنى در شرايط زوال نشان دادند كه افزايش دما و وراني درصد رطوبت در شرايط زوال، شاخصهاى جوانهزنى و دوران

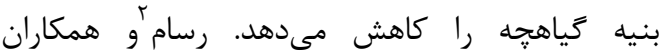

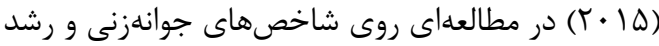
كياهجه بذر ارقام آفتابكردان در شرايط زوال بال بيان

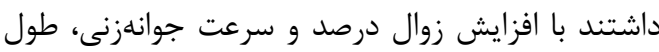

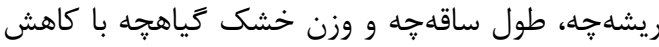
مواجه شد. در يزوهشى ديخر روى شاخصهاى جوانهزنى

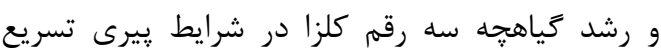

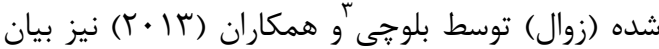

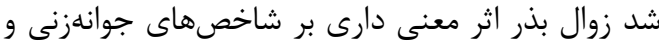

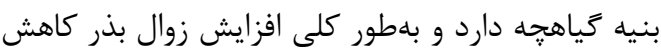

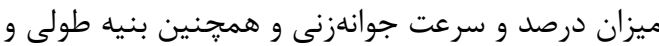
وزنى گياهجه ارقام كلزا را در يَى دارد.

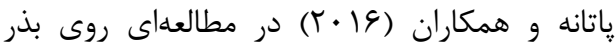
كياه سوركوم شيرين تحت شرايط دما و يتانسيل آب كزارش كردند كه به طور كلى با كاهش زمان شروع جوانهزنى شاخصهاى طولى و وزنى كياهجه افزايش مىيابد كه در نتايج اين آزمايش نيز بيشترين كاهش

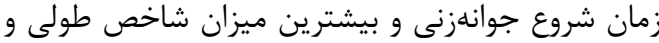

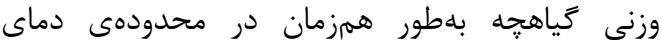

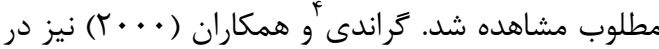

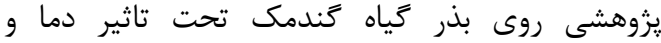
يتانسيل آب كزارش كردند كه با كاهش يتانسيل آب در كليه دماها شاخصهاى طولى و وزنى بنى بنيه كياهجه

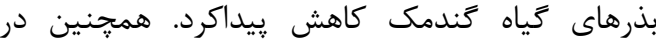
مطالعهاى روى اثرات دما و يتانسيل آب بر شاخصهاى جوانهزنى بذر گياه برى نقرهاى توسط وانَ و همكاران

\footnotetext{
${ }^{1}$ Baladi

${ }^{2}$ Ressam

${ }^{3}$ Balouchi

${ }^{4}$ Grundy
} 
جدول س. مقايسه ميانگين برهمكنش يتانسيل آب و زوال بذر، براى شاخص بنيه گياهجه بذر گياه شنبليله در دماهاى مورد آزمايش.

Table 3. Mean comparison of interaction effect of water potential and seed aging on seedling index of Fenugreek seed at experimental temperatures

\begin{tabular}{|c|c|c|c|c|c|c|c|c|}
\hline \multirow{2}{*}{$\begin{array}{c}\text { زوال بذر } \\
\text { Seed aging }\end{array}$} & \multirow{2}{*}{$\begin{array}{c}\text { يتانسيل آب } \\
\text { Water potential (MPa) }\end{array}$} & \multicolumn{7}{|c|}{ Tما Temperature $\left({ }^{\circ} \mathrm{C}\right.$} \\
\hline & & 5 & 10 & 20 & 25 & 30 & 35 & 40 \\
\hline \multirow{7}{*}{$\begin{array}{c}\text { بدون زوال } \\
\text { Non aged }\end{array}$} & 0 & $57.90^{\mathrm{a}}$ & $59.77^{\mathrm{a}}$ & $59.37^{\mathrm{a}}$ & $33.80^{\mathrm{a}}$ & $25.96^{\mathrm{a}}$ & $10.49^{\mathrm{a}}$ & $1.10^{\mathrm{a}}$ \\
\hline & -0.2 & $41.31^{\mathrm{d}}$ & $44.9^{\mathrm{c}}$ & $44.3^{\mathrm{c}}$ & $24.35^{\mathrm{b}}$ & $13.19^{c}$ & $0.48^{\mathrm{c}}$ & $0.44^{\mathrm{b}}$ \\
\hline & -0.4 & $49.21^{\mathrm{c}}$ & $50.68^{\mathrm{b}}$ & $46.95^{\mathrm{c}}$ & $1.05^{\mathrm{d}}$ & $0^{\mathrm{e}}$ & $0^{\mathrm{c}}$ & $0^{\mathrm{d}}$ \\
\hline & -0.6 & $24.73^{\mathrm{g}}$ & $27.57^{\mathrm{d}}$ & $17.73^{\mathrm{e}}$ & $0.08^{\mathrm{d}}$ & $0^{\mathrm{e}}$ & $0^{\mathrm{c}}$ & $0^{\mathrm{d}}$ \\
\hline & -0.8 & $4.71^{\mathrm{i}}$ & $5.686^{\mathrm{e}}$ & $0^{\mathrm{g}}$ & $0^{\mathrm{d}}$ & $0^{\mathrm{e}}$ & $0^{\mathrm{c}}$ & $0^{\mathrm{d}}$ \\
\hline & -1 & $0^{\mathrm{j}}$ & $0^{\mathrm{f}}$ & $0^{\mathrm{g}}$ & $0^{\mathrm{d}}$ & $0^{\mathrm{e}}$ & $0^{\mathrm{c}}$ & $0^{\mathrm{d}}$ \\
\hline & -1.2 & $0^{\mathrm{j}}$ & $0^{\mathrm{f}}$ & $0^{\mathrm{g}}$ & $0^{\mathrm{d}}$ & $0^{\mathrm{e}}$ & $0^{\mathrm{c}}$ & $0^{\mathrm{d}}$ \\
\hline \multirow{7}{*}{$\begin{array}{l}\text { زواليافته } \\
\text { Aged }\end{array}$} & 0 & $54.03^{\mathrm{b}}$ & $56.70^{\mathrm{a}}$ & $52.65^{\mathrm{b}}$ & $25.97^{\mathrm{b}}$ & $16.81^{\mathrm{b}}$ & $7.29^{\mathrm{b}}$ & $0.26^{\mathrm{c}}$ \\
\hline & -0.2 & $36.15^{\mathrm{e}}$ & $43.88^{\mathrm{c}}$ & $36.20^{\mathrm{d}}$ & $18.87^{\mathrm{c}}$ & $10.85^{\mathrm{d}}$ & $0.43^{\mathrm{c}}$ & $0^{\mathrm{d}}$ \\
\hline & -0.4 & $33.13^{\mathrm{f}}$ & $40.24^{\mathrm{c}}$ & $33.13^{\mathrm{d}}$ & $0.3^{\mathrm{d}}$ & $0^{\mathrm{e}}$ & $0^{\mathrm{c}}$ & $0^{\mathrm{d}}$ \\
\hline & -0.6 & $11.86^{\mathrm{h}}$ & $5.944^{\mathrm{e}}$ & $5.92^{\mathrm{f}}$ & $0^{\mathrm{d}}$ & $0^{\mathrm{e}}$ & $0^{\mathrm{c}}$ & $0^{\mathrm{d}}$ \\
\hline & -0.8 & $3.74^{\mathrm{i}}$ & $4.45^{\mathrm{ef}}$ & $0^{\mathrm{g}}$ & $0^{\mathrm{d}}$ & $0^{\mathrm{e}}$ & $0^{\mathrm{c}}$ & $0^{\mathrm{d}}$ \\
\hline & -1 & $0^{\mathrm{j}}$ & $0^{\mathrm{f}}$ & $0^{\mathrm{g}}$ & $0^{\mathrm{d}}$ & $0^{\mathrm{e}}$ & $0^{c}$ & $0^{\mathrm{d}}$ \\
\hline & -1.2 & $0^{\mathrm{j}}$ & $0^{\mathrm{f}}$ & $0^{\mathrm{g}}$ & $0^{\mathrm{d}}$ & $0^{\mathrm{e}}$ & $0^{\mathrm{c}}$ & $0^{\mathrm{d}}$ \\
\hline
\end{tabular}

در هر ستون، ميانكَينهاى داراى حداقل يك حرف مشترك اختلاف معنىارى را بر اساس آزمون LSD در سطح احتمال ه درصد نشان

In each column, the same letters indicate no significant difference based on the LSD test at the $5 \%$ level.

مشاهده شد. البته محيطهاى دمايى نيز بر مقادير قند

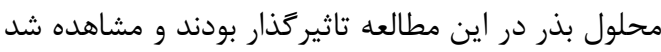
كه بهطور كلى با افزايش دما ميزان قند محلول بذر روند افزايشى دارد كه نشاندهنده اثرات افزايش دما در بيشتر شدن فعاليت آنزيمهاى هيدروليز كننده اندوخته غذايى بذر است (جدول \&). در شرايط كاهش يتانسيل آب يكسرى فرآيندهاى بيوشيميايى كه شامل كم شدن

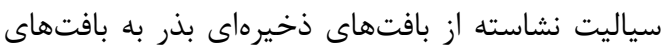

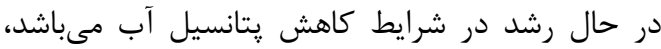
باعث كاهش جوانهزنى بذر و رشد گياهجه مي تهود. بدين

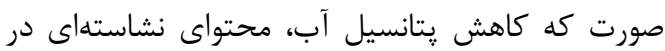
بافتهاى ذخيرهاى را افزايش داده و با اختلال در لايه آلئورون بذر فعاليت آنزيم آلفا آميلاز را كاهش ميثى دهدهد،

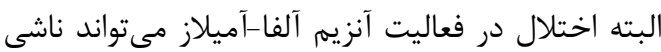
از كاهش تبديل نشاسته به كلوكز و ساكارز در بافتهاى در حال رشد باشد. رشد سلولهاى در حال تقسيم در بافت جنينى زمانى كه ساكارز در دسترس كمترى رسى
شد. البته محيطهاى دمايى نيز در ميزان قند محلول

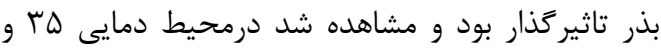

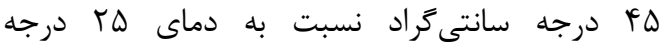
سانتى

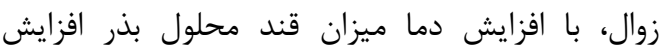
مىيابد (شكل 9). نتايج مقايسه ميانگين برهمكنش يتانسيل آب و زوال بذر بر ميزان قند محلول بذر زياه

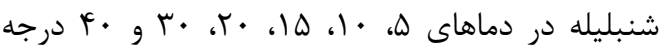
سانتى يتانسيل آب در هر دو دسته بذرهاى زواليافته و بدون

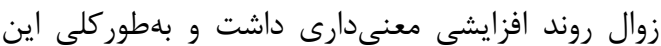
روند افزايش قند محلول، در بذرهاى زواليافته نسبت به به له بذرهاى بدون زوال بيشتر بود، همجنين افزايش قند محلول بذر در تمامى محيطهاى دمايى تحت تاثير برون كاهش يتانسيل آب و زوال بذر بلهورى بود كه بيشترين

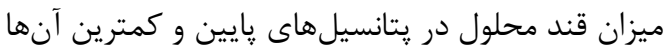

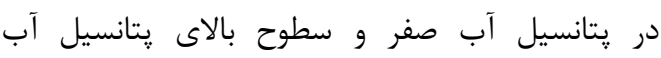



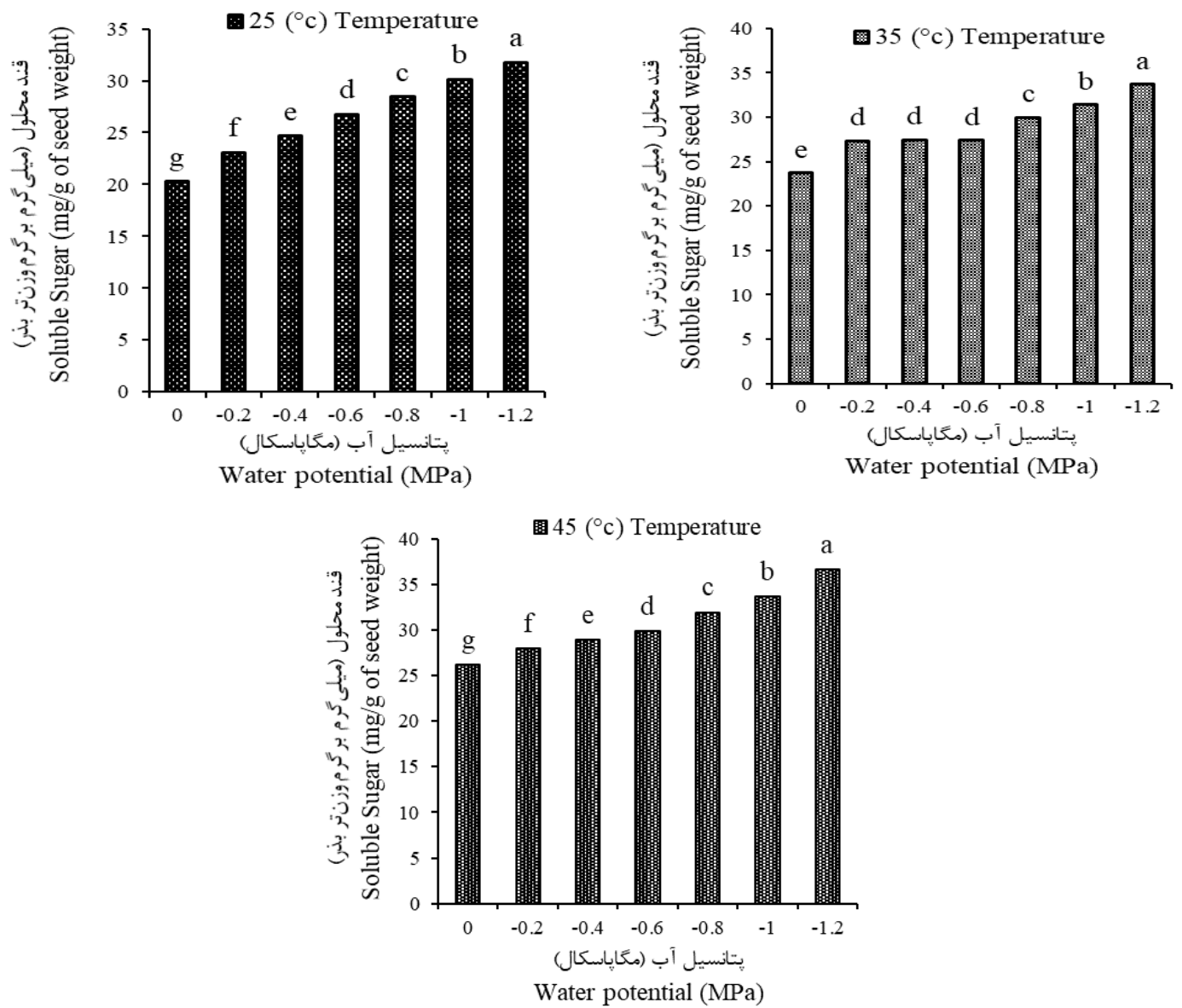

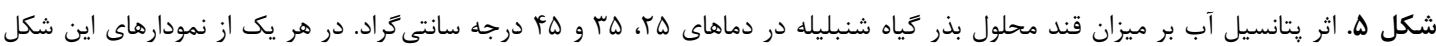

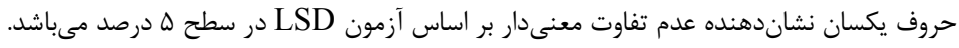

Fig. 5. The effect of water potential on soluble sugar of Fenugreek at 25, 35, and $45^{\circ} \mathrm{C}$ temperatures. In each section of this figure, the same letters indicate no significant difference based on the LSD test at the 5\% level.

آمادورى-مايلارد را تحريك كرده كه نتيجه آن تخريب

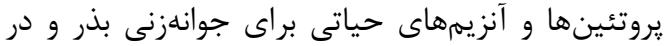

نهايت كاهش كيفيت و ميزان جوانهزنى بذر و و توليد

كياهجههاى طبيعى است. همجنين در مطالعهاى در

شرايط زوال بذر روى شاخصهاى بيوشيميايى بذر برنج

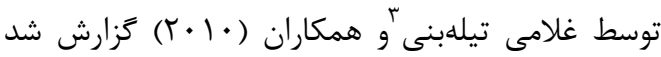

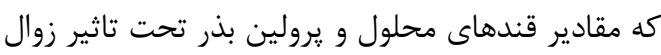

$$
\text { بذر افزايش مى ميابد. }
$$

داشته باشند، كاهش يِيدا مى كند و در نهايت اين اختلال به صورت كاهش سرعت جوانهزنى و رشد

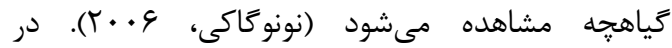

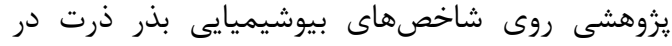
شرايط تنش خشكى و تنش شورى توسط رازانى' ورئ

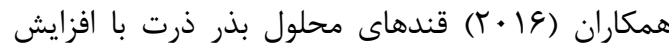

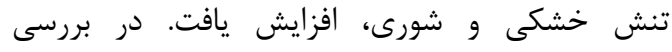

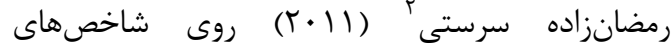
بيوشيميايى بذر زياه هنبه در شرايط زوال بذر كزارش

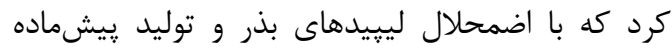
مسير كلوكونوزنز تحت تاثير شرايط زوال بذر، قندها در بذر تجمع مىيابند كه اين امر واكنشهاى مخرب

\footnotetext{
${ }^{1}$ Razani

${ }^{2}$ Ramezanzadeh Sarasti
} 

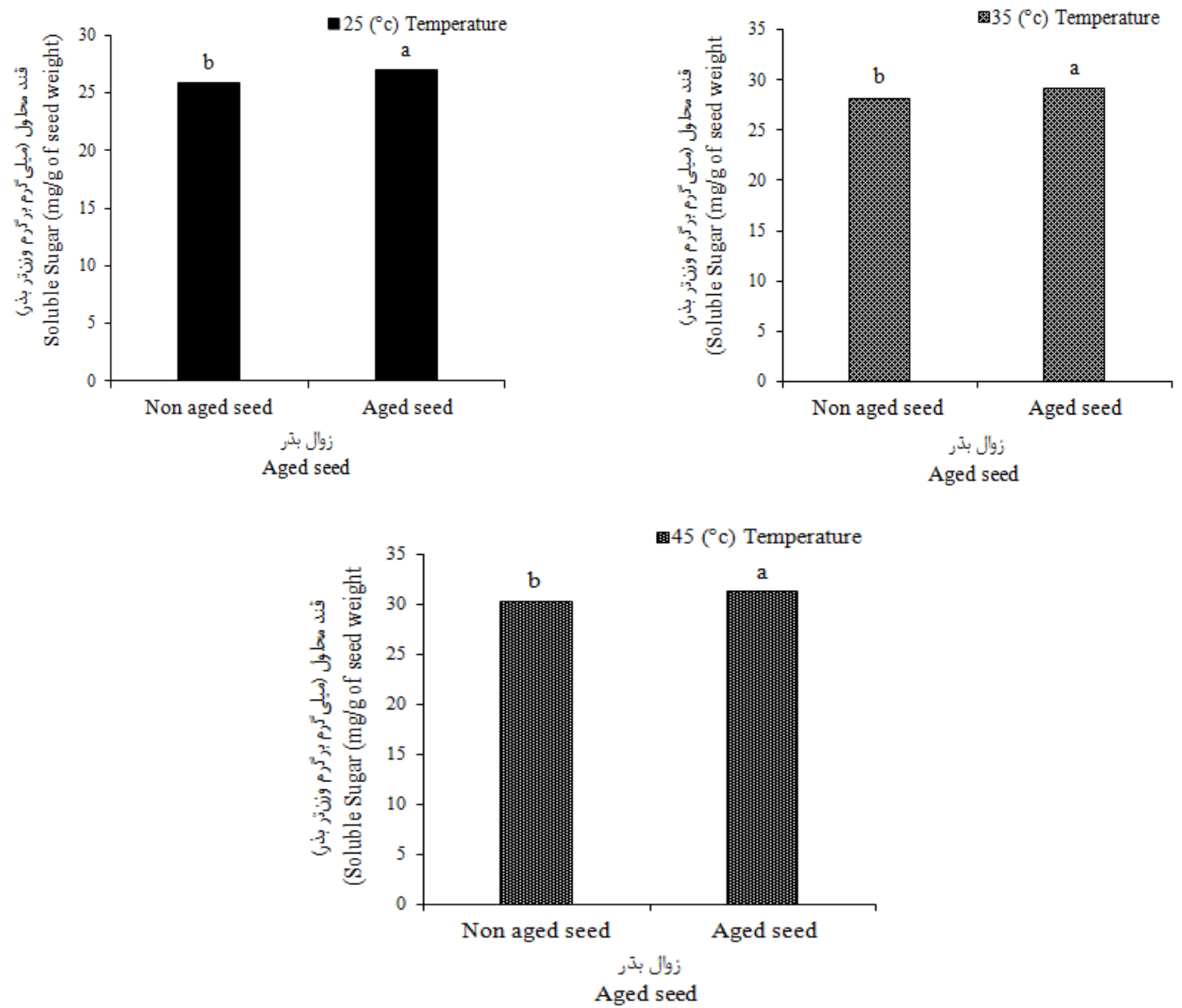

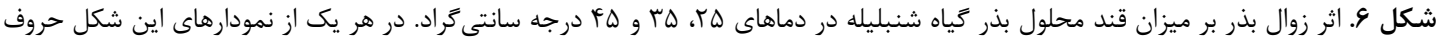

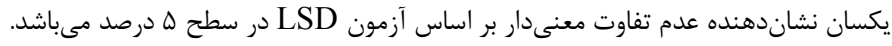

Fig. 6. The effect of seed aging on soluble sugar of Fenugreek at 25, 35, and $45{ }^{\circ} \mathrm{C}$ temperatures. In each section of this figure, the same letters indicate no significant difference based on the LSD test at the $5 \%$ level.

همجنين دادهاى مربوط به ميزان يرولين بذرهاى كياه

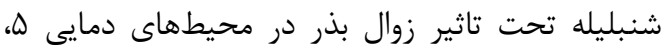

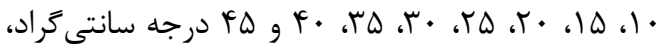
نشان داد كه با زوال بذر ميزان يرولين در بذرها افزايش

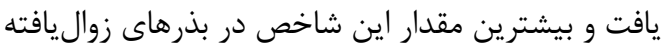

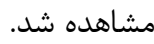

البته بر اساس نتايج مشاهده شد محيطهاى دمايى

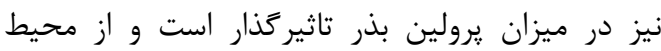
دمايى ه درجه سانتى محدودهى دماى مطلوب (دماى ·r درجه سانتى گراد)

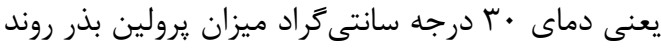

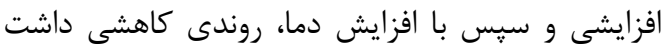
كه نشاندهنده تاثيرات مخرب دماهاى بالا در تخريب

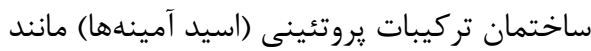

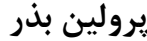
نتايج تجزيه واريانس دادههاى مربوط به يرولين بذر

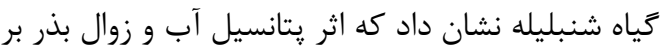
اين شاخص در تمامى دماهاى مورد آزمايش معنى دار بود ولى برهمكنش يتانسيل آب و زوال بذر در دماهاى مورى مورد آزمايش معنى دار نبود (دادهها ارائه نشده است).

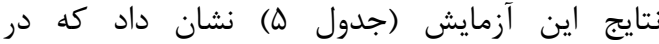

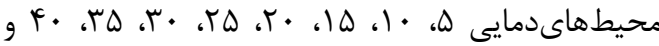

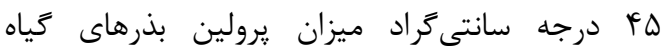
شنبليله با كاهش يتانسيل آب (كاهش دسترسى به آب)، روند افزايشى داشت. بيشترين و كمترين ميزان

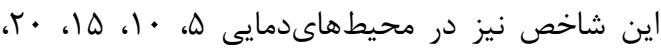

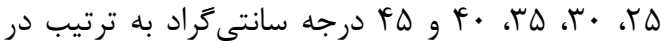
يتانسيلهاى /1/ - و صفر مخاياسكال مشاهده شد. 


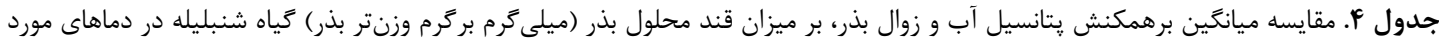

Table 4. Mean comparison of interaction effect of water potential and seed aging on sugar soluble $(\mathrm{mg} / \mathrm{g}$ seed weight) of Fenugreek seed at experimental temperatures

\begin{tabular}{|c|c|c|c|c|c|c|c|}
\hline \multirow{2}{*}{$\begin{array}{c}\text { زوال بذر } \\
\text { Seed aging }\end{array}$} & \multirow{2}{*}{$\begin{array}{c}\text { يتانسيل آب } \\
\text { Water potential (MPa) }\end{array}$} & \multicolumn{6}{|c|}{ Temperature $\left({ }^{\circ} \mathrm{C}\right)$ los } \\
\hline & & 5 & 10 & 15 & 20 & 30 & 40 \\
\hline \multirow{7}{*}{$\begin{array}{c}\text { بدون زوال } \\
\text { Non aged }\end{array}$} & 0 & $15.16^{\mathrm{i}}$ & $16.4^{\mathrm{k}}$ & $18.33^{\mathrm{h}}$ & $19.23^{\mathrm{i}}$ & $23.5^{\mathrm{h}}$ & $25.1^{\mathrm{g}}$ \\
\hline & -0.2 & $16.73^{\mathrm{h}}$ & $18.5^{\mathrm{j}}$ & $19.43^{\mathrm{g}}$ & $22.03^{\mathrm{h}}$ & $25.53^{\mathrm{g}}$ & $26.43^{\mathrm{f}}$ \\
\hline & -0.4 & $18.16^{\mathrm{g}}$ & $18.6^{\mathrm{j}}$ & $20.56^{\mathrm{f}}$ & $24.26^{\mathrm{fg}}$ & $26.63^{\mathrm{f}}$ & $28.83^{\mathrm{e}}$ \\
\hline & -0.6 & $19.66^{\mathrm{f}}$ & $21.7^{\mathrm{g}}$ & $22.16^{\mathrm{e}}$ & $24.96^{\mathrm{efg}}$ & $28.06^{\mathrm{e}}$ & $30.33^{\mathrm{d}}$ \\
\hline & -0.8 & $21.13^{\mathrm{e}}$ & $23.56^{\mathrm{ef}}$ & $23.03^{\mathrm{e}}$ & $25.83^{\mathrm{de}}$ & $26.6^{\mathrm{fg}}$ & $30.63^{\mathrm{d}}$ \\
\hline & -1 & $22.76^{\mathrm{d}}$ & $25.03^{\mathrm{cd}}$ & $25.6^{\mathrm{c}}$ & $26.93^{\mathrm{c}}$ & $31.23^{\mathrm{bc}}$ & $32.16^{\mathrm{c}}$ \\
\hline & -1.2 & $25.36^{\mathrm{b}}$ & $26.53^{\mathrm{b}}$ & $27.46^{\mathrm{b}}$ & $29.56^{\mathrm{b}}$ & $30.3^{\mathrm{cd}}$ & $32.53^{\mathrm{c}}$ \\
\hline \multirow{7}{*}{$\begin{array}{c}\text { زوال يافته } \\
\text { Aged }\end{array}$} & 0 & $16.63^{\mathrm{h}}$ & $17^{\mathrm{k}}$ & $19.53^{\mathrm{g}}$ & $20.06^{\mathrm{i}}$ & $24.03^{\mathrm{h}}$ & $24.9^{\mathrm{g}}$ \\
\hline & -0.2 & $18.43^{\mathrm{g}}$ & $19.56^{\mathrm{i}}$ & $20.13^{\mathrm{fg}}$ & $24.03^{\mathrm{g}}$ & $26^{\mathrm{fg}}$ & $28.8^{\mathrm{e}}$ \\
\hline & -0.4 & $19.53^{\mathrm{f}}$ & $20.7^{\mathrm{h}}$ & $21.03^{\mathrm{f}}$ & $25.13^{\mathrm{ef}}$ & $26.76^{\mathrm{f}}$ & $29.2^{\mathrm{e}}$ \\
\hline & -0.6 & $21.76^{\mathrm{e}}$ & $22.73^{\mathrm{f}}$ & $24.03^{\mathrm{d}}$ & $27^{\mathrm{c}}$ & $28.73^{\mathrm{e}}$ & $31^{\mathrm{d}}$ \\
\hline & -0.8 & $23.8^{\mathrm{c}}$ & $24.4^{\mathrm{de}}$ & $24.23^{\mathrm{d}}$ & $26.33^{\mathrm{cd}}$ & $29.9^{\mathrm{d}}$ & $32.26^{\mathrm{c}}$ \\
\hline & -1 & $25.73^{\mathrm{b}}$ & $25.5^{\mathrm{c}}$ & $26.83^{\mathrm{b}}$ & $29.33^{\mathrm{b}}$ & $32.16^{\mathrm{b}}$ & $35.23^{\mathrm{b}}$ \\
\hline & -1.2 & $28.33^{\mathrm{a}}$ & $30.43^{\mathrm{a}}$ & $30.96^{\mathrm{a}}$ & $32.5^{\mathrm{a}}$ & $34.53^{\mathrm{a}}$ & $36.26^{\mathrm{a}}$ \\
\hline
\end{tabular}

In each column, the same letters indicate no significant difference based on the LSD test at the 5\% level.

جدول ه. مقايسه ميانكين برهمكنش يتانسيل آب و زوال بذر، بر ميزان برولين بذر (ميكرومول بركرم وزنتر بذر) كياه شنبليله در دماهاى مورد آزمايش.

Table 5. Mean comparison of interaction effect of water potential and seed aging on proline ( $\mu \mathrm{mol} / \mathrm{g}$ seed weight) of Fenugreek seed at experimental temperatures

\begin{tabular}{|c|c|c|c|c|c|c|c|c|c|c|}
\hline \multirow{2}{*}{\multicolumn{2}{|c|}{$\begin{array}{c}\text { تيمار } \\
\text { Treatment }\end{array}$}} & \multicolumn{9}{|c|}{ دما Temperature $\left({ }^{\circ} \mathrm{C}\right.$} \\
\hline & & 5 & 10 & 15 & 20 & 25 & 30 & 35 & 40 & 45 \\
\hline \multirow{7}{*}{$\begin{array}{c}\text { يتانسيل آب } \\
\text { Water } \\
\text { potential } \\
\text { (MPa) }\end{array}$} & 0 & $0.8635^{\mathrm{e}}$ & $1.087^{\mathrm{e}}$ & $1.240^{\mathrm{d}}$ & $1.573^{\mathrm{e}}$ & $1.662^{\mathrm{e}}$ & $2.104^{\mathrm{e}}$ & $1.950^{\mathrm{e}}$ & $1.841^{\mathrm{d}}$ & $1.796^{\mathrm{d}}$ \\
\hline & -0.2 & $1.131^{\mathrm{d}}$ & $1.310^{\mathrm{e}}$ & $1.419^{\mathrm{d}}$ & $1.886^{\mathrm{d}}$ & $1.990^{\mathrm{d}}$ & $2.297^{\mathrm{de}}$ & $2.07^{\mathrm{e}}$ & $2.109^{c}$ & $2.109^{\mathrm{c}}$ \\
\hline & -0.4 & $1.488^{\mathrm{c}}$ & $1.623^{\mathrm{d}}$ & $1.702^{\mathrm{c}}$ & $2.094^{\mathrm{cd}}$ & $2.228^{\mathrm{cd}}$ & $2.521^{\mathrm{cd}}$ & $2.397^{\mathrm{d}}$ & $2.169^{\mathrm{c}}$ & $2.198^{\mathrm{c}}$ \\
\hline & -0.6 & $1.802^{\mathrm{b}}$ & $1.985^{\mathrm{c}}$ & $2.030^{\mathrm{b}}$ & $2.318^{\mathrm{c}}$ & $2.377^{\mathrm{c}}$ & $2.715^{\mathrm{bc}}$ & $2.456^{\mathrm{cd}}$ & $2.511^{\mathrm{b}}$ & $2.58^{\mathrm{b}}$ \\
\hline & -0.8 & $1.965^{\mathrm{b}}$ & $2.104^{b c}$ & $2.223^{\mathrm{b}}$ & $2.362^{\mathrm{bc}}$ & $2.660^{\mathrm{b}}$ & $2.819^{\mathrm{b}}$ & $2.71^{\mathrm{bc}}$ & $2.466^{\mathrm{b}}$ & $2.72^{\mathrm{b}}$ \\
\hline & -1 & $2.322^{\mathrm{a}}$ & $2.402^{\mathrm{ab}}$ & $2.521^{\mathrm{a}}$ & $2.630^{\mathrm{b}}$ & $2.854^{\mathrm{ab}}$ & $3.132^{\mathrm{a}}$ & $2.963^{\mathrm{ab}}$ & $2.943^{\mathrm{a}}$ & $2.794^{b}$ \\
\hline & -1.2 & $2.501^{\mathrm{a}}$ & $2.596^{\mathrm{a}}$ & $2.744^{\mathrm{a}}$ & $2.943^{\mathrm{a}}$ & $2.943^{\mathrm{a}}$ & $3.251^{\mathrm{a}}$ & $3.157^{\mathrm{a}}$ & $3.032^{\mathrm{a}}$ & $3.092^{\mathrm{a}}$ \\
\hline \multirow{2}{*}{$\begin{array}{c}\text { زوال بذر } \\
\text { Seed } \\
\text { aging }\end{array}$} & Non aged & $1.452^{\mathrm{b}}$ & $1.620^{\mathrm{b}}$ & $1.728^{\mathrm{b}}$ & $2.081^{\mathrm{b}}$ & $2.148^{\mathrm{b}}$ & $2.460^{\mathrm{b}}$ & $2.334^{b}$ & $2.227^{b}$ & $2.213^{\mathrm{b}}$ \\
\hline & aged & $1.998^{\mathrm{a}}$ & $2.124^{\mathrm{a}}$ & $2.237^{\mathrm{a}}$ & $2.435^{\mathrm{a}}$ & $2.627^{\mathrm{a}}$ & $2.922^{\mathrm{a}}$ & $2.724^{\mathrm{a}}$ & $2.650^{\mathrm{a}}$ & $2.728^{\mathrm{a}}$ \\
\hline
\end{tabular}

In each treatment and column, the same letters indicate no significant difference based on the LSD test at the 5\% level. 


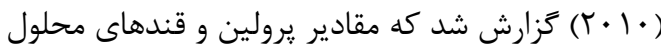
بذر تحت تاثير زوال بذر افزايش مى يابد كه بهطور كلى بادي نتايج يزوهش حاضر نيز مشابهت داشت.

\section{محتواى يروتئين محلول بذر}

نتايج تجزيه واريانس دادههاى مربوط به يروتئين

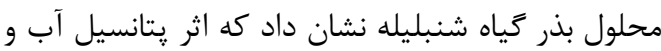

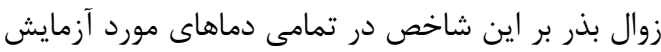

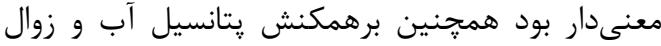

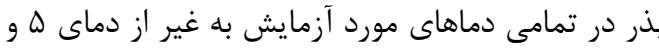
•r درجه سانتى گراد معنى دار بود (دادهها ارائه نشده است). نتايج اين آزمايش نشان داد كه در محيطهاى

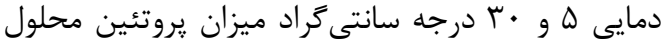
بذرهاى كياه شنبليله با كاهش رِتانسيل آب (كاهش دسترسى به آب)، روندى افزايشى داشت. بيشترين و كمترين ميزان اين شاخص نيز در محيطهاىدمايى ها هو

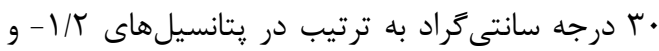

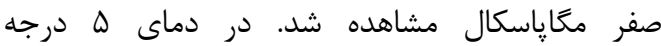
سانتى گراد نيز ميزان يروتئين بذر در سطوح يتانسيل

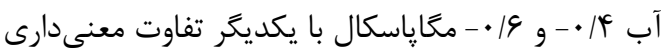
نداشت، همجنين به دليل اثركذارى محيطهاى دمايى

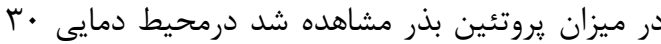
درجه سانتى تمامى سطوح يتانسيل آب با افزايش دما، ميزان بروتئين

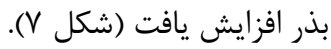
نتايج اين يزوهش نشان داد كه در محيطهاى دمايى

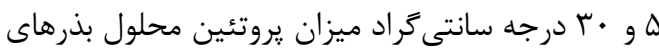

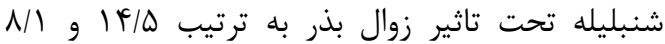
درصد افزايش يافت و بيشترين مقدار اين شاخص در درائر

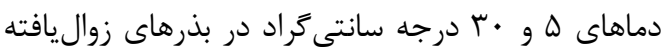

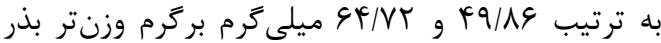
مشاهده شد. محيطهاى دمايى نيز در ميزان يروتئين

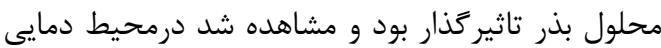
•r در جه سانتى كراد نسبت به دماى له درجه سانتى كراد

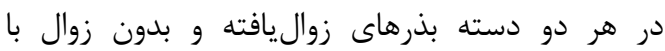
افزايش دما ميزان يروتئين بذر افزايش يافت (شكل م) دون. نتايج مقايسه ميانگين برهمكنش يتانسيل آب و ورئ زوال بذر بر ميزان يروتئين بذر كياه شنبليله در دماهاى
يرولين و آنزيمهاى بذر است (قادرىفر و همكاران،

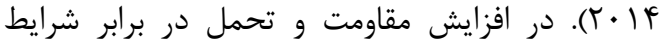
تنش در سلولهاى كياهى تركيباتى ديخرى نيز به جز تركيبات آنتىاكسيدانتى، وجود دارند كه با حضور در دري اطراف غشاى سلول، باعث حفظ آماس و ويتانسيل اسمزى در دو طرف سلول مىشوند. قندهاى محلول و

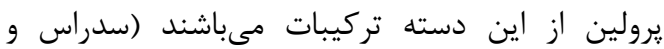

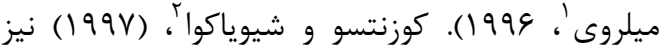
بيان كردند كه يرولين از طريق جلوكيرى از تخريب آنزيمها و از بين بردن راديكال برداى هيدروكسيل و همجنين تنظيم اسمزى درون سلول، مقاومت و تحمل

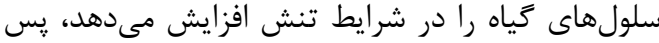
افزايش :برولين در سلولهاى گياهى هنغام مواجه شدن با شرايط تنش نوعى مكانيسم دفاعى است و انباشته

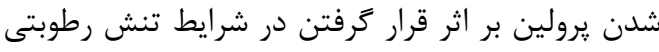

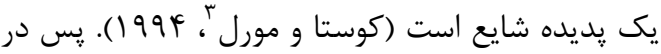

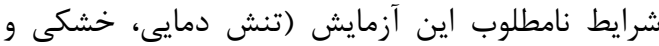
زوال بذر) افزايش تركيباتى خون يرولين و قند محلول بذر در جهت حفظ ساختار ديوارمى سلولى، تنظيم اسمزى درون سلول و جلوكيرى از تخريب تركيبات

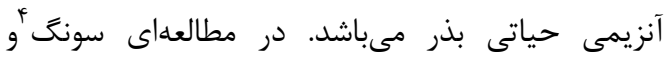

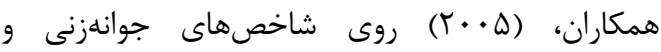
بيوشيميايى بذر گياه گندم در شرايط تنش دمايى و

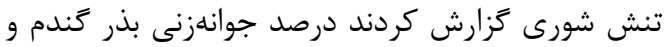

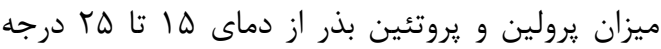

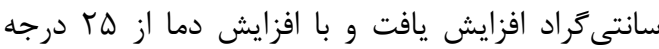

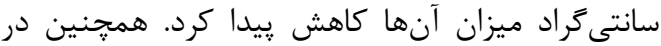

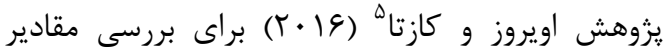
يرولين بذر كياه ذرت در مرحله جوانهزنى تحت شرايط

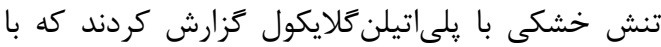

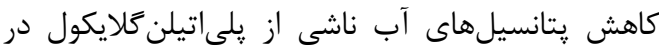

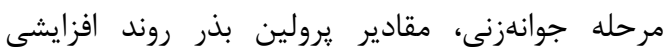
داشت. در يزوهشى در شرايط زوال بذر روى شاخصهاى بيوشيميايى بذر برنج توسط غلامى تيلهبنى و همكاران

\footnotetext{
${ }^{1}$ Sadras and Milroy

${ }^{2}$ Kuznetsov and Shevyakova

${ }^{3}$ Costa and Morel

${ }^{4}$ Song

${ }^{5}$ Queiroz and Cazetta
} 
يروتئين بذر در اين مطالعه تاثير گذار بود و بهطور كلى با افزايش دما ميزان يروتئين محلول بذر روند افزايشى

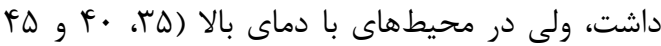

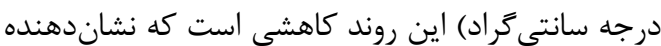
اثرات مخرب دماهاى بالا در تخريب ساختار تركيبات

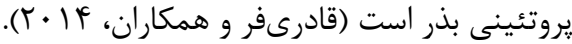
روند افزايش يروتئين بذر در اين آزمايش تحت شرايط كاهش دسترسى به آب نشان داد كه همانند

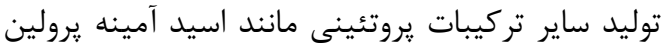

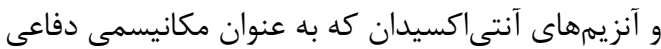

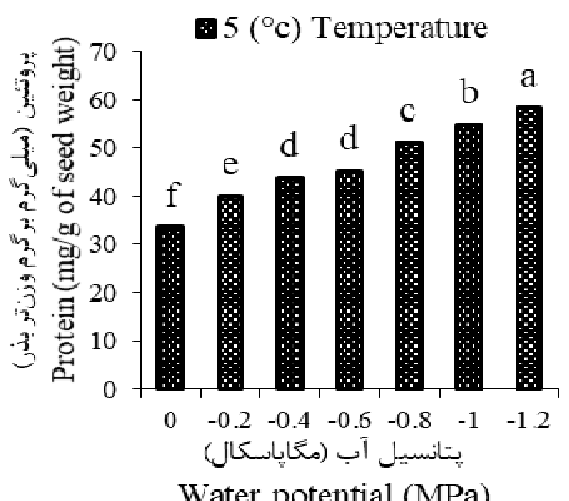

Water potential (MPa) •l، (جدول 9) نشان داد كه يروتئين بذر با كاهش يتانسيل آب در هر دو دسته بذرهاى زواليافته و بدون زوال روند افزايشى داشت و بهطور كلى مقادير اين افزايش تروتئين، در بذرهاى زواليافته نسبت به بذرهاى بدون زوال

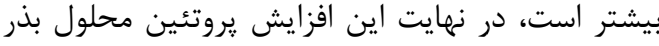
در محيطهاى دمايى تحت تاثير كاهش يتانسيل آب و زوال بذر بهطورى بود كه بيشترين ميزان يروتئين در

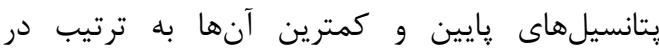
يتانسيل آب صفر مغاياسكال و سطوح بالاى يتانسيل آب مشاهده شد. البته محيطهاى دمايى نيز بر مقادير

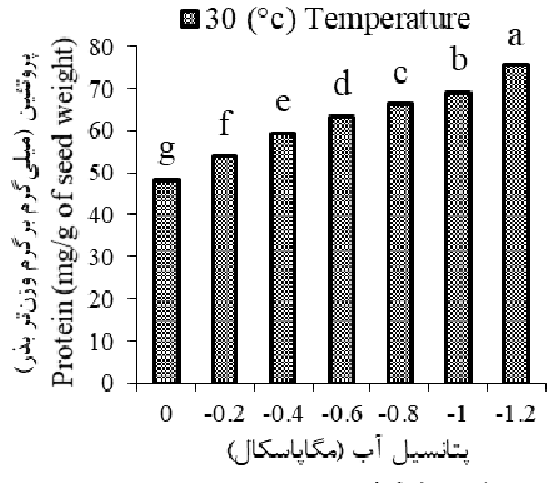

Water potential (MPa)

شكل V. اثر يتانسيل آب بر ميزان يروتئين بذر كياه شنبليله در دماهاى ه و • ب درجه سانتى كراد. در هر يك از نمودارهاى اين شكل حروف

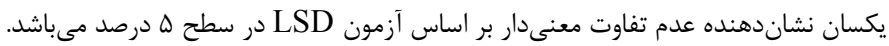

Fig. 7. The effect of water potential on protein of Fenugreek at 5 and $30{ }^{\circ} \mathrm{C}$ temperatures. In each section of this figure, the same letters indicate no significant difference based on the LSD test at the 5\% level.
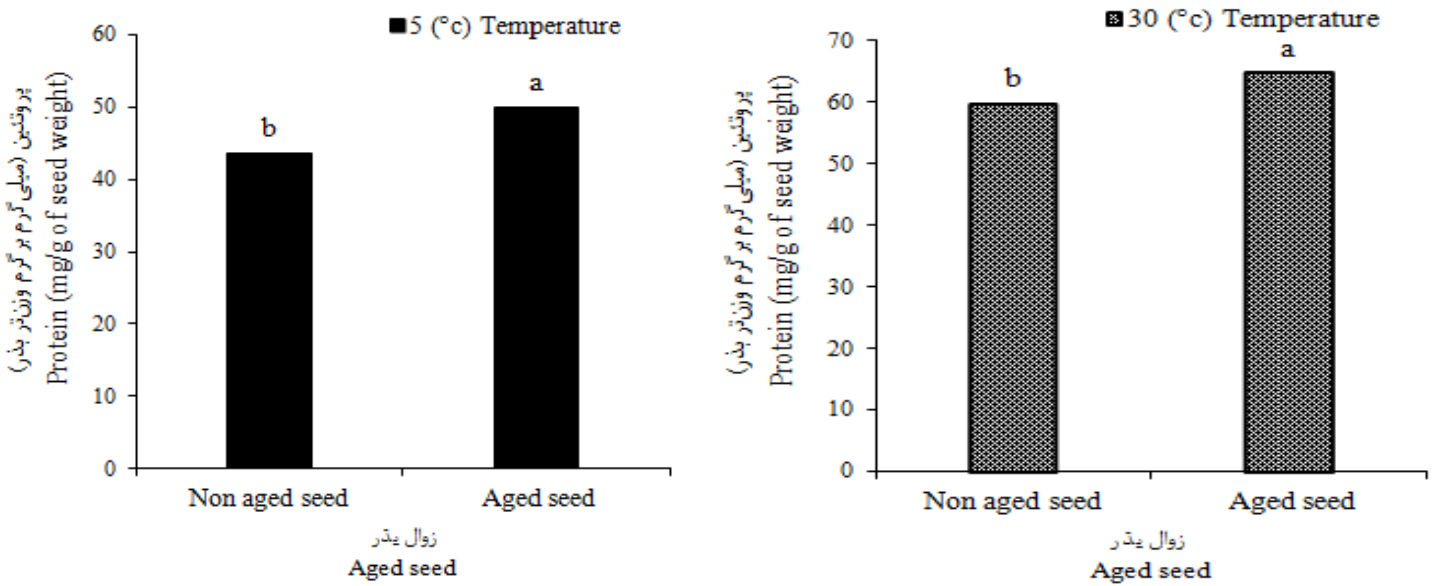

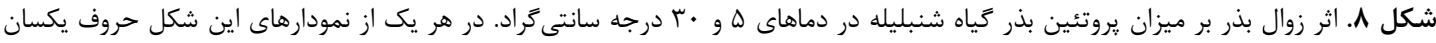

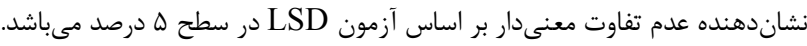

Fig. 8. The effect of seed aging on protein of Fenugreek at 5 and $30^{\circ} \mathrm{C}$ temperatures. In each section of this figure, the same letters indicate no significant difference based on the LSD test at the $5 \%$ level. 
كاهش يِيدا كرد كه نشاندهنده اثرات مخرب دماهاى

بالا در تخريب ساختار تركيبات يروتئينى بذر بود.

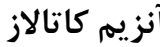

نتايج تجزيه واريانس دادههاى مربوط به ميزان

فعاليت آنزيم كاتالاز بذر كياه شنبليله نشان داد كه اثر دئر

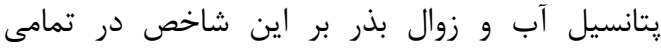
دماهاى مورد آزمايش معنىدار بود، البته برهمكنش آنش يتانسيل آب و زوال بذر بر ميزان فعاليت آنزيم كاتالاز

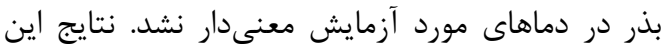

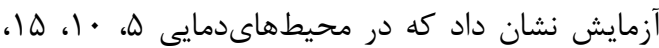
•r

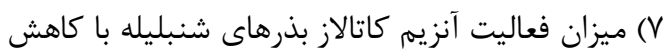

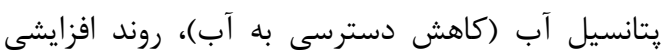

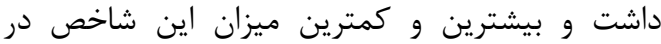

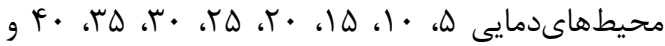

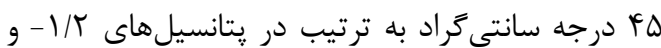

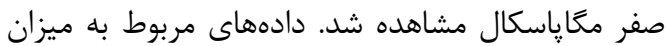

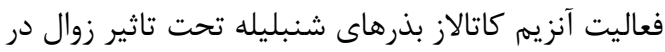

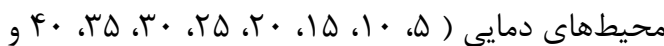

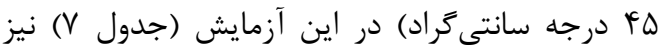

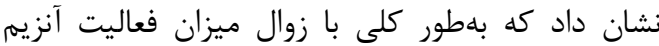
كاتالاز در بذرها افزايش يافت و بيشترين مقادير كاتالاز

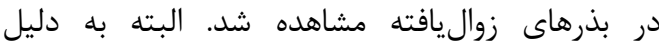

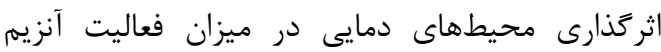
كاتالاز بذر (جدول V) نيز مشاهده شد كه از محيط دمان

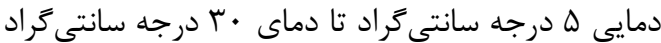
كه كمى بعد از محدودهى دماى مطلوب (دمائ درجه سانتى گراد) مىباشد، ميزان فعاليت آنزيم كاتالاز بذر روند افزايشى و سيس با افزايش دما از اين محدودهه، روندى كاهشى دارد كه نشاندهنده اثرات مخرب دماهاى بالا در تخريب ساختار تركيبات يروتئينى

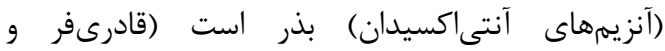

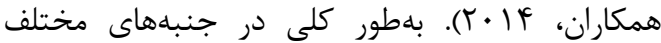

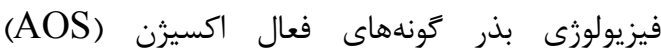
تاثير كذار مىباشند و آزاد شدن كونههاى اكسيرن فعال در طى شرايط تنشى جون كاهش دسترسى به آب، زوال

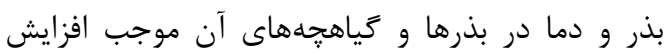

براى مقابله با شرايط تنش خشكى مىباشند، افزايش

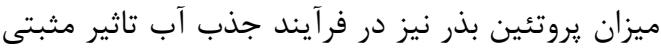

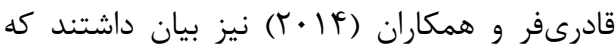

بين افزايش يروتئين بذر و مقدار جذب آب توسط بذر

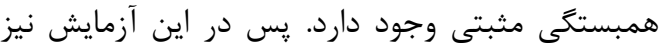

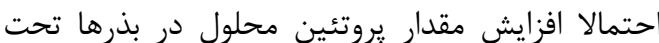

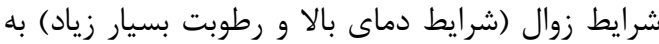
غير از افزايش ساير تركيبات يروتئينى (آنزيمهاى

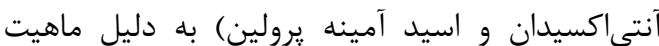

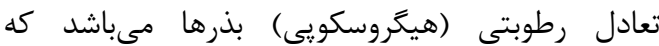
نشاندهنده توانايى بذر در برقرارى تعادل رطوبتى بين

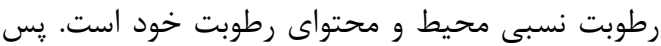
در شرايط زوال كه ميزان رطوبت نسبى محيط افزايش مىيابد، رطوبت بذرها نيز افزايش ويدا كرده و در نتيجها

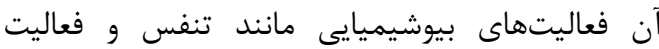
آنزيمهاى هيدروليز كننده مانند يروتئزازها افزايش مى يابد كه افزايش محتواى يروتئين محلول بذر را در يى إيى دارد و البته اتر اين شرايط زوال (دماى بالا و رطوبت برديت بسيار زياد) ادامه يابد، باعث كاهش ميزان يروتئين بذر بتر

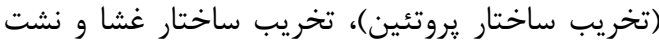
مواد درون سلول و در انتها باعث از بين رفتن سلول

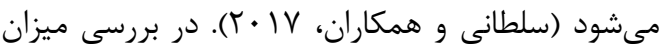
محتواى يروتئين بذر كرجك در شرايط زوال سلطانى و

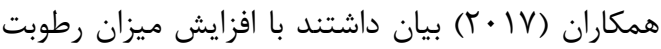
انبار، رطوبت بذرها افزايش ييدا كرد و موجب افزايش

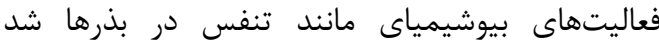
همجنين ايشان كزارش كردند در ابتداى انباردارى محتواى يروتئين محلول بذرها افزايش يافت و با ادامه دورهى انباردارى و كاهش ذخاير غذايى بذر و كاهش

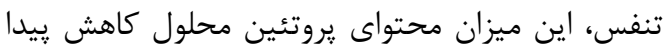
كرد. در يزوهشى ديخر روى شاخصهاى جوانهزنى و بيوشيميايى بذر كندم در شرايط تنش دمايى توسط

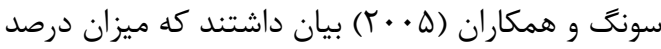
جوانهزنى بذر كندم و ميزان يرولين و يروتئين بذر از

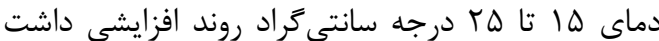

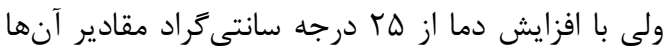


جدول 9. مقايسه ميانكين برهمكنش يتانسيل آب و زوال بذر، بر ميزان بروتئين بذر (ميلى كرم بركرم وزنتر بذر) كياه شنبليله در دماهاى مورد آزمايش.

Table 6. Mean comparison of interaction effect of water potential and seed aging on protein ( $\mathrm{mg} / \mathrm{g}$ of seed weight) of Fenugreek seed at experimental temperatures

\begin{tabular}{|c|c|c|c|c|c|c|c|c|}
\hline \multirow{2}{*}{$\begin{array}{c}\text { زوال بذر } \\
\text { Seed aging }\end{array}$} & \multirow{2}{*}{$\begin{array}{c}\text { يتانسيل آب } \\
\text { Water potential } \\
(\mathrm{MPa})\end{array}$} & \multicolumn{7}{|c|}{ Tomperature $\left({ }^{\circ} \mathrm{C}\right)$} \\
\hline & & 10 & 15 & 20 & 25 & 35 & 40 & 45 \\
\hline \multirow{7}{*}{$\begin{array}{c}\text { بدون زوال } \\
\text { Non aged }\end{array}$} & 0 & $31.03^{\mathrm{g}}$ & $34.96^{\mathrm{g}}$ & $37.73^{j}$ & $38.6^{\mathrm{h}}$ & $44.9^{\mathrm{h}}$ & $44.26^{j}$ & $40.56^{\mathrm{h}}$ \\
\hline & -0.2 & $41.96^{\mathrm{ef}}$ & $44.43^{\mathrm{e}}$ & $47.56^{\mathrm{i}}$ & $51.06^{\mathrm{f}}$ & $48.73^{\mathrm{g}}$ & $47.93^{\mathrm{hi}}$ & $45.66^{\mathrm{g}}$ \\
\hline & -0.4 & $44.5^{\mathrm{de}}$ & $46.8^{\mathrm{e}}$ & $51.16^{\mathrm{gh}}$ & $54.26^{\mathrm{ef}}$ & $50.2^{\mathrm{g}}$ & $53^{\mathrm{g}}$ & $48.76^{\mathrm{fg}}$ \\
\hline & -0.6 & $45.73^{\mathrm{de}}$ & $50.8^{\mathrm{d}}$ & $52.9^{\mathrm{fg}}$ & $55.1^{\mathrm{de}}$ & $62.3^{\mathrm{cd}}$ & $58.8^{\mathrm{de}}$ & $57.56^{\mathrm{d}}$ \\
\hline & -0.8 & $47.86^{\mathrm{cd}}$ & $53.56^{\mathrm{cd}}$ & $53.26^{\mathrm{fg}}$ & $58.43^{\mathrm{cd}}$ & $60.16^{\mathrm{d}}$ & $58.76^{\mathrm{de}}$ & $60.2^{\mathrm{d}}$ \\
\hline & -1 & $55.9^{\mathrm{b}}$ & $55.23^{\mathrm{bc}}$ & $60.06^{\mathrm{cd}}$ & $68.8^{\mathrm{b}}$ & $61.96^{\mathrm{cd}}$ & $60.53^{\mathrm{d}}$ & $63.46^{\mathrm{c}}$ \\
\hline & -1.2 & $58.43^{\mathrm{b}}$ & $57^{\mathrm{b}}$ & $63.13^{\mathrm{bc}}$ & $71.2^{\mathrm{b}}$ & $66.56^{\mathrm{b}}$ & $70.56^{\mathrm{b}}$ & $65.8^{\mathrm{bc}}$ \\
\hline \multirow{7}{*}{$\begin{array}{l}\text { زواليافته } \\
\text { Aged }\end{array}$} & 0 & $39.3^{\mathrm{f}}$ & $40.56^{\mathrm{f}}$ & $45.53^{\mathrm{i}}$ & $46.16^{\mathrm{g}}$ & $55.8^{\mathrm{e}}$ & $47.56^{\mathrm{i}}$ & $50.8^{\text {ef }}$ \\
\hline & -0.2 & $45.96^{\mathrm{cd}}$ & $50.5^{\mathrm{d}}$ & $48.3^{\mathrm{hi}}$ & $57.46^{\text {cde }}$ & $55.63^{\mathrm{e}}$ & $51.06^{\mathrm{gh}}$ & $53.06^{\mathrm{e}}$ \\
\hline & -0.4 & $49.73^{c}$ & $50.5^{\mathrm{d}}$ & $58.26^{\mathrm{de}}$ & $55.2^{\mathrm{de}}$ & $52.06^{\mathrm{fg}}$ & $53.73^{\mathrm{fg}}$ & $52.66^{\mathrm{e}}$ \\
\hline & -0.6 & $46.86^{\mathrm{cd}}$ & $52.7^{\mathrm{cd}}$ & $55.83^{\mathrm{ef}}$ & $59.43^{\mathrm{c}}$ & $54.16^{\mathrm{ef}}$ & $56.26^{\mathrm{ef}}$ & $51.56^{\mathrm{ef}}$ \\
\hline & -0.8 & $59.3^{\mathrm{b}}$ & $57.2^{\mathrm{b}}$ & $62.16^{\mathrm{c}}$ & $70.96^{\mathrm{b}}$ & $64.8^{\mathrm{bc}}$ & $64.23^{\mathrm{c}}$ & $67.46^{\mathrm{ab}}$ \\
\hline & -1 & $63.23^{\mathrm{a}}$ & $64.43^{\mathrm{a}}$ & $66.56^{\mathrm{ab}}$ & $75.03^{\mathrm{a}}$ & $67.5^{\mathrm{b}}$ & $70.83^{b}$ & $68.86^{\mathrm{ab}}$ \\
\hline & -1.2 & $65.66^{\mathrm{a}}$ & $66.16^{\mathrm{a}}$ & $70.03^{\mathrm{a}}$ & $77.03^{\mathrm{a}}$ & $71.6^{\mathrm{a}}$ & $75.43^{\mathrm{a}}$ & $70.6^{\mathrm{a}}$ \\
\hline
\end{tabular}

In each column, the same letters indicate no significant difference based on the LSD test at the $5 \%$ level.

جدول Vا. مقايسه ميانكَين برهمكنش يتانسيل آب و زوال بذر، بر ميزان فعاليت آنزيم كاتالاز بذر (ميلىمول بر گَرم وزنتر بذر بر دقيقه) گياه شنبليله در دماهاى مورد آزمايش.

Table 7. Mean comparison of interaction effect of water potential and seed aging on Catalase enzyme (mmol/g seed weight per minute) of Fenugreek seed at experimental temperatures

\begin{tabular}{|c|c|c|c|c|c|c|c|c|c|c|}
\hline \multirow{2}{*}{\multicolumn{2}{|c|}{$\begin{array}{c}\text { تيمار } \\
\text { Treatment }\end{array}$}} & \multicolumn{9}{|c|}{ Tomperature $\left({ }^{\circ} \mathrm{C}\right)$} \\
\hline & & 5 & 10 & 15 & 20 & 25 & 30 & 35 & 40 & 45 \\
\hline \multirow{7}{*}{$\begin{array}{c}\text { يتانسيل آب } \\
\text { Water potential } \\
\text { (MPa) }\end{array}$} & 0 & $0.054^{\mathrm{f}}$ & $0.062 \mathrm{e}$ & $0.070^{\mathrm{d}}$ & $0.077 \mathrm{e}$ & $0.080^{\mathrm{d}}$ & $0.094^{\mathrm{d}}$ & $0.092^{\mathrm{d}}$ & $0.084^{\mathrm{d}}$ & $0.081 \mathrm{e}$ \\
\hline & -0.2 & $0.066 \mathrm{e}$ & $0.075^{\mathrm{d}}$ & $0.083^{\mathrm{c}}$ & $0.086^{\mathrm{d}} \mathrm{e}$ & $0.098^{\mathrm{c}}$ & $0.108^{\mathrm{cd}}$ & $0.099^{\mathrm{cd}}$ & $0.098^{\mathrm{cd}}$ & $0.089^{\mathrm{d}} \mathrm{e}$ \\
\hline & -0.4 & $0.073^{\mathrm{de}}$ & $0.080^{\text {cd }}$ & $0.084^{\mathrm{c}}$ & $0.092^{\text {cd }}$ & $0.100^{\mathrm{c}}$ & $0.106^{\text {cd }}$ & $0.109^{b c}$ & $0.103^{b c}$ & $0.100^{\text {cd }}$ \\
\hline & -0.6 & $0.079^{\mathrm{cd}}$ & $0.084^{\text {cd }}$ & $0.093^{b c}$ & $0.104^{\mathrm{bc}}$ & $0.107^{\mathrm{bc}}$ & $0.116^{\mathrm{bc}}$ & $0.113^{\mathrm{bc}}$ & $0.110^{\mathrm{bc}}$ & $0.108^{\mathrm{bc}}$ \\
\hline & -0.8 & $0.086^{\mathrm{bc}}$ & $0.092^{\mathrm{bc}}$ & $0.099^{\mathrm{ab}}$ & $0.105^{\mathrm{bc}}$ & $0.109^{\mathrm{bc}}$ & $0.121^{\mathrm{abc}}$ & $0.117^{\mathrm{ab}}$ & $0.108^{\mathrm{bc}}$ & $0.112^{\mathrm{abc}}$ \\
\hline & -1 & $0.098^{\mathrm{ab}}$ & $0.101^{\mathrm{ab}}$ & $0.105^{\mathrm{ab}}$ & $0.114^{\mathrm{ab}}$ & $0.117^{\mathrm{ab}}$ & $0.127^{\mathrm{ab}}$ & $0.123^{\mathrm{ab}}$ & $0.118^{\mathrm{ab}}$ & $0.118^{\mathrm{ab}}$ \\
\hline & -1.2 & $0.102^{\mathrm{a}}$ & $0.107^{\mathrm{a}}$ & $0.111^{\mathrm{a}}$ & $0.120^{\mathrm{a}}$ & $0.124^{\mathrm{a}}$ & $0.135^{\mathrm{a}}$ & $0.130^{\mathrm{a}}$ & $0.128^{\mathrm{a}}$ & $0.124^{\mathrm{a}}$ \\
\hline \multirow{2}{*}{$\begin{array}{c}\text { زوال بذر } \\
\text { Seed aging }\end{array}$} & Non aged & $0.066^{\mathrm{b}}$ & $0.072^{\mathrm{b}}$ & $0.082^{\mathrm{b}}$ & $0.089^{\mathrm{b}}$ & $0.097^{\mathrm{b}}$ & $0.104^{\mathrm{b}}$ & $0.105^{\mathrm{b}}$ & $0.099^{\mathrm{b}}$ & $0.096^{\mathrm{b}}$ \\
\hline & Aged & $0.093^{\mathrm{a}}$ & $0.099^{\mathrm{a}}$ & $0.103^{\mathrm{a}}$ & $0.110^{\mathrm{a}}$ & $0.113^{\mathrm{a}}$ & $0.126^{\mathrm{a}}$ & $0.119^{\mathrm{a}}$ & $0.115^{\mathrm{a}}$ & $0.113^{\mathrm{a}}$ \\
\hline
\end{tabular}

In each treatment and column, the same letters indicate no significant difference based on the LSD test at the $5 \%$ level.

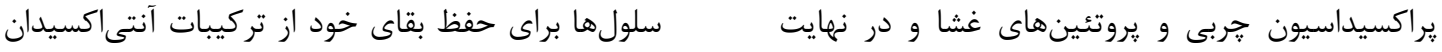

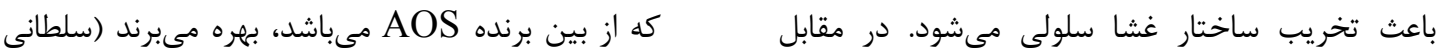


بيوشيميايى بذر (قند محلول، يروتئين محلول، يرولين و

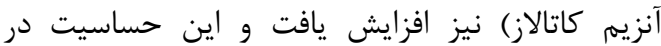
شاخصهاى جوانهزنى و بيوشيميايى بذر نسبت به به آنسين

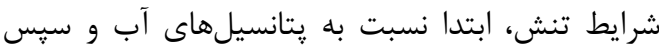
زوال بذر و محيطهاى دمايى بود. همجنين روند تغييرات شاخصهاى جوانهزنى (درصد و و سرعت جوانهزنى) بذر كياه شنبليله تحت تأثير كاهش يتانسيلهاى آب و محيطهاى دمايى نشان داد كه بيشترين ميزان درصد و سرعت جوانهزنى در شرايط كاهش دسترسى به آب (تنش خشكى) در محيطهاى دمايى يايينتر از دماى مطلوب جوانهزنى (•r درجه سانتى

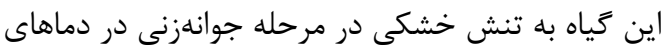

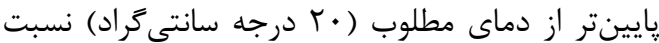

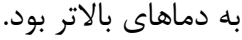

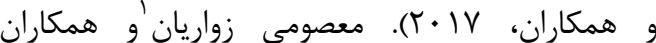

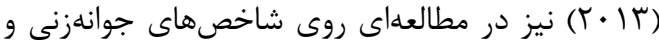

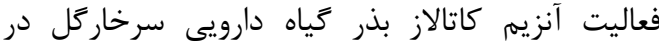
شرايط تنش خشكى بيان داشتند با افزايش تنش خشكى فعاليت آنزيم كاتالاز بذرهاى سرخاركل افزايش

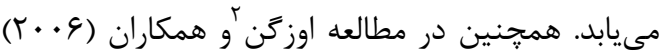
براى ارزيابى فعاليت آنزيمهاى آنتىاكسيدان بذرهاى

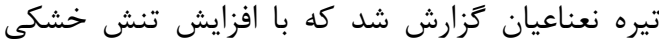

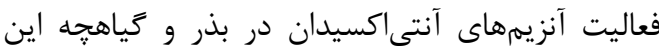
تيره روند افزايشى داشت. بلوجى و استاديانبيدكلى آنى

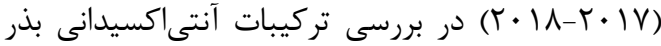
كتان روغنى رقم نورمن و توده محلى بزرك قرمز در

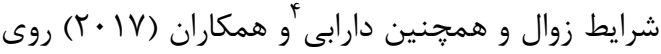
تركيبات آنتى|كسيدانى بذر ارقام هيبريد ذرت در در شرايط زوال كزارش كردند كاهش مقادير شاخصهاى جوانهزنى

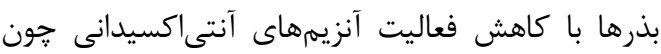
كاتالاز، سويراكسيدديسموتاز و آسكوربات يراكسيداز

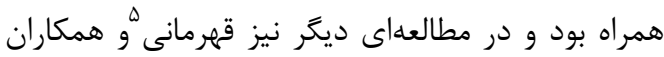

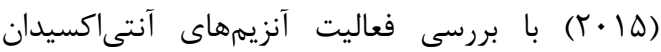
بذرهاى فرسوده گياه كدوى تخم كاغذى، كزارش كردند

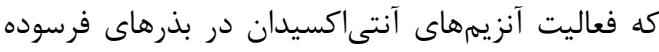
نسبت به شاهد بيشتر بود. در نهايت بر اساس نتايج

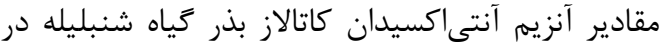
اين مطالعه مىتوان كزارش كرد كه روند افزايشى ميزان

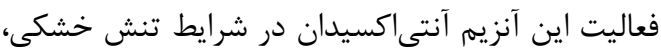
زوال بذر و محيطهاى دمايى در جهت كاهش اثرئ اثرات مخرب تنشروى بذر اين گياه بود.

نتيجه

نتايج نشان داد تحت تاثير پِيرى تسريعشده (زوال)

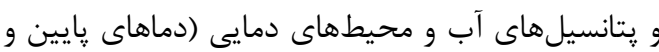
بالاى دماى مطلوب)، بلهور كلى مقادير شاخصهاى جوانهزنى شنبليله (درصد و سرعت جوانهزنى و بنيه كياهجه) روند كاهشى داشت و مقادير تركيبات

\footnotetext{
${ }^{1}$ Masoumi Zavariyan

${ }^{2}$ Ozgen

${ }^{3}$ Balouchi and Ostadian Bidgoly

${ }^{4}$ Darabi

${ }^{5 .}$ Qahremani
} 
Abdul-Baki, A.A., and Anderson, J.D. 1973. Vigor determination in soybean seed by Multiple criteria. Crop Science, 630-633. https://doi.org/10.2135/cropsci1973.0011183X001300060013x

Aebi, H. 1984. Catalase in vitro. In: Methods in Enzymology. Elsevier, 105: 121-126.

Akram Ghaderi, R., Soltani, E., and Sadeghipor, H.R. 2008. Biochemical changes in Pumpkin seeds affected by premature aging. Third Congress of Medicinal Plants. Shahed University, Tehran. [In Persian].

Alavi, S.H. Zand, E. Delkhosh, B. Ghajar, F., and Alipour, H. 2014. Study on the effect of different temperatures on the seed germination of Rosinweed (Cressa cretica) in the Rafsanjan pistachio orchards. Iranian Pistachio Magazine, 1(1): 49-57. [In Persian with English Summary].

Bakhshandeh, E., and Gholamhossieni, M. 2018. Quantification of soybean seed germination response to seed deterioration under peg-induced water stress using hydrotime concept. Acta Physiologiae Plantarum, 40(7): 126. https://doi.org/10.1007/s11738-018-2700-1

Baladi, S., Balouchi, H., Moradi, A., and Movahedi Dehnavi, M. 2016. The Effect of different temperatures and moisture during storage period on germination indices of Linum usitatissimum L. Iranian Journal of Seed Science and Technology, 5(1): 107-122.

Balouchi H.R., Bagheri, F., Kayednezami, R., Movahedi Dehnavi, M., and Yadavi, A.R. 2013. Effect of seed aging on germination and seedling growth indices in three cultivars of Brassica napus. Journal of Plant Researches, 26(4): 397-411. [In Persian with English Summary].

Balouchi, H.R., and Ostadian Bidgoli, R. 2017. Effect of seed deterioration on physiological and biochemical traits of oilflax (Linum usitatssimum L. Norman Var.) seed. The Plant Production (Scientific Journal of Agriculture), 40(2): 37-52. [In Persian with English Summary].

Balouchi, H.R., and Ostadian Bidgoli, R. 2018. Effect of seed deterioration on germination and antioxidant enzymes activity of oil flax (Linum usitatissimum L.) Red Bazrak genotype Journal of Plant Process and Function. 7(23): 205-218. [In Persian with English Summary].

Barsa, S.M.A., Ahmad, N., Khan, M.M., Iqbal, N., and Cheema, M.A. 2003. Assessment of cotton seed deterioration during accelerated ageing. Seed Science and Technology, 31: 531-540. https://doi.org/10.15258/sst.2003.31.3.02

Baskin, C.C., and Baskin, J.M. 2001. Seeds: Ecology, biogeography, and evolution of dormancy and germination. Elsevier.

Bewley, J.D., and Black, M. 1994. Seeds. In: Seeds. Springier. 1-33. https://doi.org/10.1007/9781-4899-1002-8_ 1 https://doi.org/10.1007/978-1-4899-1002-8

Bradford, K.J. 2002. Applications of hydrothermal time to quantifying and modeling seed germination and dormancy. Weed Science, 50(2): 248-260. https://doi.org/10.1614/00431745(2002)050[0248:AOHTTQ]2.0.CO;2

Costa, G., and Morel, J. 1994. Water relations, gas exchange and amino acid content in cd-treated lettuce. Plant Physiology and Biochemistry, 32(4): 561-570.

Darabi, F., Valipour M., Naseri, R., and Moradi, M. 2017. The effect of accelerated aging on germination and antioxidant activity of maize hybrids (Zea mays). Iranian Journal of Seed Research, 4(1): 45-59. [In Persian with English Summary]. https://doi.org/10.29252/yujs.4.1.45

Finch-Savage, W., Dent, K., and Clark, L. 2004. Soak conditions and temperature following sowing influence the response of maize (Zea mays L.) seeds to on-farm priming (pre-sowing seed soak). Field Crops Research, 90(2-3): 361-374. https://doi.org/10.1016/j.fcr.2004.04.006 
Gallashi, S., Farzaneh, F., Soltani. A., and Rezaei. C. 2007. Evaluation of drought stress in forty cotton genotypes at germination stage. Journal of Agricultural Science and Natural Resources, 13(2): 43-51. [In Persian with English Summary].

Ghaderifar, F., Kamkar, B., and Soltani, A. 2014. Seed Science and Technology. (Copland, L., and McDonald. M.B. 1936.) Translated, Jahad University Press of Mashhad, 512 p. [In Persian].

Ghahremani, P., Sedghi, M., and Tavakoli, H. 2015. Effect of gibberellin and salicylic acid on germination characteristics and activity of antioxidant enzymes in sunflower seeds. Journal of Seed Research, 5(2): 29-20. [In Persian with English Summary].

Gholami Tilehbeni, M., Babayan, S., Mosavinik, M. and Ahmadian, A. 2010. Evaluation of heterotrophic growth of rice seedling and prolin and solution sugars Concentrations changes under seed deterioration levels. Fifth National Conference on New Ideas in Agriculture. Islamic Azad University of Khorasgan Branch (Isfahan), Faculty of Agriculture. [In Persian].

Grundy, A., Phelps, K., Reader, R., and Burston, S. 2000. Modelling the germination of stellaria media using the concept of hydrothermal time. New Phytologist, 148(3): 433-444. https://doi.org/10.1046/j.1469-8137.2000.00778.x

Hegarty, T. 1978. The physiology of seed hydration and dehydration, and the relation between water stress and the control of germination: A review. Plant, Cell and Environment, 1(2): 101119. https://doi.org/10.1111/j.1365-3040.1978.tb00752.x

Irigoyen, J., Einerich, D., and Sánchez Diaz, M. 1992. Water stress induced changes in concentrations of proline and total soluble sugars in nodulated alfalfa (Medicago sativa) plants. Physiologia Plantarum, 84(1): 55-60. https://doi.org/10.1034/j.1399-3054.1992.840109.x https://doi.org/10.1111/j.1399-3054.1992.tb08764.x

Kamkar, B., Al-Alahmadi, M.J., Mahdavi-Damghani, A., and Villalobos, F.J. 2012. Quantification of the cardinal temperatures and thermal time requirement of opium poppy (Papaver somniferum L.) seeds to germinate using non-linear regression models. Industrial Crops and Products, 35(1): 192-198. https://doi.org/10.1016/j.indcrop.2011.06.033

Kar, M., and Mishra, D. 1976. Catalase, peroxidase, and polyphenoloxidase activities during rice leaf senescence. Plant Physiology, 57(2): 315-319. https://doi.org/10.1104/pp.57.2.315

Kuznetsov, V.V., and Shevyakova, N.I. 1997. Stress responses of tobacco cells to high temperature and salinity. Proline accumulation and phosphorylation of polypeptides. Physiologia Plantarum, 100(2): $\quad 320-326 . \quad$ https://doi.org/10.1111/j.1399-3054.1997.tb04789.x https://doi.org/10.1034/j.1399-3054.1997.1000214.x

Maguire, J.D. 1962. Speed of germination-aid in selection and evaluation for seedling emergence $\begin{array}{lllll}\text { and vigor. } & \text { Crop } & \text { Science, } & \text { 176-177. }\end{array}$ https://doi.org/10.2135/cropsci1962.0011183X000200020033x

Masumi Zavariyan, A., Yousefirad, M., and Asghari, M. 2013. The effect of drought stress on germination indicators and the amount of proline and catalase, in the the seed of milk thistle medicinal plant. First National Conference on Agricultural Science, Payame Noor UniversityWest Azarbaijan-Naghdeh. [In Persian].

Meyer, S.E., and Pendleton, R.L. 2000. Genetic regulation of seed dormancy in Purshia tridentata (rosaceae). Annals of Botany, 85(4): 521-529. https://doi.org/10.1006/anbo.1999.1099

Michel, B.E., and Kaufmann, M.R. 1973. The osmotic potential of polyethylene glycol 6000. Plant Physiology, 51(5): 914-916. https://doi.org/10.1104/pp.51.5.914

Nonogaki, H. 2006. Seed germination-the biochemical and molecular mechanisms. Breeding Science, 56(2): 93-105. https://doi.org/10.1270/jsbbs.56.93

Ostadian Bidgoli, R., Balouchi, H.R., Soltani, E., and Moradi, A. 2017. Effects of temperature and water potential on seed germination characteristics in Safflower (Carthamus tinctorius L.) 
Sofeh var. Iranian Journal of Seed Science and Technology, 6(1): 11-22. [In Persian with English Summary].

Ozgen, U., Mavi, A., Terzi, Z., Yildirim, A., Coskun, M., and Houghton, P. 2006. Antioxidant properties of some medicinal Lamiaceae (Labiatae) species. Pharmaceutical Biology, 44(2): 107-112. https://doi.org/10.1080/13880200600592061

Paquin, R., and Lechasseur, P. 1979. Observations sur une methode de dosage de la proline libre dans les extraits de plantes. Canadian Journal of Botany, 57(18): 1851-1854. https://doi.org/10.1139/b79-233

Patane, C., Saita, A., Tubeileh, A., Cosentino, S.L., and Cavallaro, V. 2016. Modeling seed germination of unprimed and primed seeds of sweet sorghum under peg-induced water stress through the hydrotime analysis. Acta Physiologiae Plantarum, 38(5): 115. https://doi.org/10.1007/s11738-016-2135-5

Queiroz, R.J., and J.O. Cazetta. 2016. Proline and trehalose in maize seeds germinating under low osmotic potentials. Revista Brasileira de Engenharia Agrícola e Ambiental, 20(1): 22-28. https://doi.org/10.1590/1807-1929/agriambi.v20n1p22-28

Rajabi Khamseh, S., Danesh Shahraki, A.R., and Ghobadi Nia, M. 2015. Effect of drought stress on germination and seedling growth of Linum usitatissimum L. The first international conference and the $4^{\text {th }}$ National Conference on Plants of Judging and Sustainable Agriculture. Hamedan-Permanent Secretariat of the Conference. [In Persian].

Ramezanzadeh Sarasti, N. 2011. Investigating mechanisms of deterioration in cotton seed: lipid peroxidation and hydrolysis of sugars. Master's Degree in Agriculture. University of Agricultural Sciences and Natural Resources Gorgan. [In Persian].

Rassam, G., Rahban S, Mojtabaii M., and Badri A. 2015. Effect of seed aging on germination and seedling growth of sunflower (Helianthus annuus) cultivars. Iranian Journal of Seed Research, 1(2): 115-123. [In Persian with English Summary].

Razani M., Mir Mohammadi, T., and Jalilnejad, N. 2016. The effect of polyethylene glycol surfaces on biochemical properties and dry weight of maize plant seed. Third Conference on New Findings in the Environment and Agricultural Ecosystems, Tehran, New Energy and Environment Institute of University of Tehran. [In Persian].

Rehman, S., Harris, P. and Bourne, W. 1999. Effect of artificial ageing on the germination, ion leakage and salinity tolerance of Acacia tortilis and A. coriacea seeds. Seed Science and Technology, 27(1): 141-149.

Ruveyda, T. 2011. Salinity exposure modifies nutrient concentration in fenugreek (Trigonella founum greacum L.). African Journal of Agriculture, 6(16): 3685-3690.

Sadras, V., and Milroy, S. 1996. Soil-water thresholds for the responses of leaf expansion and gas exchange: A review. Field Crops Research, 47(2-3): 253-266. https://doi.org/10.1016/0378$\underline{4290(96) 00014-7}$

Shaaban, M. 2016. Effect of aging on enzymatic and non-enzymatic antioxidant changes and biochemical characteristics in barley (Hordeum vulgare L.) seeds cv. Valfajr. Iranian Journal of Seed Science and Research, 3(3): 79-93. [In Persian with English Summary].

Soltani, A., Robertson, M., Torabi, B., Yousefi-Daz, M., and Sarparast, R. 2006. Modelling seedling emergence in chickpea as influenced by temperature and sowing depth. Agricultural and Forest Meteorology, 138(1): 156-167. https://doi.org/10.1016/j.agrformet.2006.04.004

Soltani, M., Moradi, A., Tavakol Afshari, R., and Balouchi, H.R. 2017. Effect of different storage conditions on germination and some biochemical characteristics of castor bean (Ricinus communis) seed. Iranian Journal of Field Crop Science, 48(1): 91-105. [In Persian with English Summary]. 
Song, S., Lei, Y., and Tian, X. 2005. Proline metabolism and cross-tolerance to salinity and heat stress in germinating wheat seeds. Russian Journal of Plant Physiology, 52(6): 793-800. https://doi.org/10.1007/s11183-005-0117-3

Tavakol Afshari, R., Ghasemian, F., Majnon Hosseini, N., Alizadeh, H., and Bihamta, M.R. 2007. The effect of early aging on germination and activity of antioxidant enzymes catalase and peroxidase in barley genotypes. Iranian Journal of Agricultural Science, 38(2): 337-346. [In Persian with English Summary].

Teimori, H., and Balouchi, H.R. 2017. The effect of accelerated aging on germination Fenugreek (Trigonella foenum-graecum).4th Seed Science and Technology congress, Karaj. Payam Nour University. [In Persian with English Summary].

Verma, S., Verma, U., and Tomer, R. 2003. Studies on seed quality parameters in deteriorating seeds in brassica (Brassica campestris). Seed Science and Technology, 31(2): 389-396. https://doi.org/10.15258/sst.2003.31.2.15

Wang, R., Bai, Y., and Tanino, K. 2006. Seedling emergence of winterfat (Krascheninnikovia lanata (pursh) adj meeuse \& smit) in the field and its prediction using the hydrothermal time model. Journal of Arid Environments, 64(1): 37-53. https://doi.org/10.1016/j.jaridenv.2005.04.017

Zamani, A., saadatnoori, S.A. Tavakol Afshari, R., Irannejad. H., Akbari, J.U., and Tavakoli, A. 2010. Evaluation of lipid peroxidation and activity of some antioxidant enzymes in safflower seeds under natural and artificial senescence conditions. Iranian Journal of Field Crop Science (Agricultural Sciences of Iran), 41(3): 545-554. [In Persian with English Summary]. 


\title{
Effect of Seed Aging and Water Potential on Seed Germination and Biochemical Indices of Fenugreek (Trigonella foenum-graecum) at Different Temperatures
}

\begin{abstract}
Hasan Teimori ${ }^{1}$, Hamidreza Balouchi ${ }^{2,{ }^{*}}$, Elias Soltani ${ }^{3}$, Ali Moradi ${ }^{2}$
Extended abstract

Introduction: Seed germination is one of the most important and complex stages in the plant life cycle and is affected by many hereditary and environmental factors. Various factors affect germination and seedling establishment. Among these factors are the characteristics of the maternal plant (nutrition, genetics), seed treatment stage at harvest time as well as environmental factors (temperature, water potential, and ventilation and soil compaction). In addition, under the influence of seed loss during storage, seed vigor, which is known as the first component of seed quality, decreases. The aim of this study was to investigate germination and biochemichal responses of the aged seeds of Fenugreek to different temperature and humidity ranges.

Materials and Methods: This experiment was conducted as a factorial based on a completely randomized design with four replications in the Laboratory of Seed Science and Technology, Faculty of Agriculture, Yasouj University in 2016. The experimental treatments consisted of nine levels of temperature $(5,10,15,20,25,30,35,40$ and 45 degrees Celsius), water potential comprised seven levels (zero (control), $-0.2,-0.4,-0.6,-0.8,-1$ and $-1.2 \mathrm{MPa}$ ) and seed aging at two levels (no aged (control) and aged seed).

Results: In this experiment, the effect of seed aging, water potential and their interactions in each environment on germination indices (germination percentage and germination rate, length and weight vigor index) and biochemical indices (soluble sugar, proline, soluble protein and catalase enzymes) of Fenugreek seeds were significant. The results showed that in the aged seeds, the germination percentage and rate and seedling vigor index tended to decrease with water potential reduction at temperatures below and above 20 degrees Celsius, whereas the amount of biochemical components of the seeds (soluble sugar, soluble protein, proline, and catalase enzyme) increased.

Conclusion: In general, germination and biochemical indices of seeds of Fenugreek are sensitive to water potentials, aging, and seed germination temperatures, respectively. In case of reduction in osmotic potential, the germination temperature less than $20^{\circ} \mathrm{C}$ resulted in increased germination resistance of fenugreek seeds to a more negative water potential.
\end{abstract}

\section{Keywords: Catalase, Drought stress, Germination percentage, Proline, Seed vigor, Soluble Sugar}

\section{Highlights:}

1-Investigation of germination and biochemical properties of fenugreek aged seeds under different levels of osmotic potantials and temperatures.

2- In areas with a lower osmotic potential, it is advisable to cultivate Fenugreek seeds at temperatures below $20^{\circ} \mathrm{C}$.

\footnotetext{
${ }^{1}$ M.Sc. Student of Seed Science and Technology, Agronomy and Plant Breeding Department, Yasouj University, Yasouj, Iran

${ }^{2}$ Associate Professor and Assistant Professor of Agronomy and Plant Breeding Department, Yasouj University, Yasouj, Iran

${ }^{3}$ Assistant Professor Agronomy and Plant Breeding Department, Pardis Aboryhan, Tehran University, Tehran, Iran

*Corresponding author, E-mail address: balouchi@yu.ac.ir
} 